Article

\title{
Tetracopper(II) Cores Driven by an Unexplored Trifunctional Aminoalcohol Sulfonic Acid for Mild Catalytic C-H Functionalization of Alkanes
}

\author{
Inês F. M. Costa ${ }^{1}$, Marina V. Kirillova ${ }^{1, *}$, Vânia André ${ }^{1}$, Tiago A. Fernandes ${ }^{1}$ and \\ Alexander M. Kirillov 1,2,*(D) \\ 1 Centro de Química Estrutural, Instituto Superior Técnico, Universidade de Lisboa, Av. Rovisco Pais, \\ 1049-001 Lisboa, Portugal; inesfmcosta@outlook.com (I.F.M.C.); vaniandre@tecnico.ulisboa.pt (V.A.); \\ tiago.a.fernandes@tecnico.ulisboa.pt (T.A.F.) \\ 2 Research Institute of Chemistry, Peoples' Friendship University of Russia (RUDN University), \\ 6 Miklukho-Maklaya st., 117198 Moscow, Russia \\ * Correspondence: kirillova@tecnico.ulisboa.pt (M.V.K.); kirillov@tecnico.ulisboa.pt (A.M.K.); \\ Tel.: +351-218417178 (M.V.K.)
}

Received: 4 March 2019; Accepted: 15 March 2019; Published: 1 April 2019

\begin{abstract}
Three new tetracopper(II) coordination compounds were easily generated from $\mathrm{Cu}\left(\mathrm{NO}_{3}\right)_{2}$, a trifunctional aminoalcohol sulfonic acid ( $\mathrm{H}_{3}$ bes, $N$,N-bis(2-hydroxyethyl)-2-aminoethanesulfonic acid) as a principal building block, and a benzene carboxylic acid as a supporting ligand (i.e., benzoic (Hba), 4-hydroxybenzoic (Hfba), or 3-hydroxybenzoic (Hthba) acid). The obtained microcrystalline products, $\left[\mathrm{Cu}_{4}(\mu-\mathrm{Hbes})_{3}\left(\mu-\mathrm{H}_{2}\right.\right.$ bes $\left.)(\mu-\mathrm{L})\right] \cdot 2 \mathrm{H}_{2} \mathrm{O}\left(\mathrm{L}=\mathrm{ba}^{-}(\mathbf{1}), \mathrm{fhba}^{-}(2)\right.$, and thba $\left.{ }^{-}(3)\right)$, were fully characterized by FTIR (Fourier-transform infrared spectroscopy), elemental analysis, ESI-MS (Electrospray Ionisation Mass Spectrometry), and single-crystal X-ray diffraction methods. Compounds 1-3 were applied as effective homogeneous catalysts in the oxidative $\mathrm{C}-\mathrm{H}$ functionalization of alkanes (cycloalkanes and propane). Two different model reactions were explored: (1) mild oxidation of alkanes with hydrogen peroxide to give alcohols and ketones, and (2) mild carboxylation of alkanes with carbon monoxide, water, and potassium peroxodisulfate to give carboxylic acids. For these reactions, effects of different parameters, as well as mechanistic and selectivity characteristics, were studied.
\end{abstract}

Keywords: copper; homogeneous catalysis; cycloalkanes; propane; oxidation; carboxylation; $\mathrm{C}-\mathrm{H}$ functionalization; bioinspired systems

\section{Introduction}

The search for active catalytic systems and novel protocols toward mild C-H functionalization of saturated hydrocarbons represents a challenging research direction with relevance to areas of homogeneous and heterogeneous catalysis, as well as coordination and organic chemistry [1-12]. Alkanes represent a class of compounds that are particularly attractive for the synthesis of industrially valuable products [1-3]. However, these naturally abundant carbon raw materials have limitations on their synthetic use due to the high inertness. Thus, saturated hydrocarbons are mainly converted, via energy-demanding processes, into more reactive intermediates (e.g., olefins, syngas) for subsequent large-scale organic synthesis [1-3].

Considering these factors, there is a growing interest for the development of effective and single-step protocols for the oxidative transformation of saturated hydrocarbons, including the tuning of reaction conditions and the selection of appropriate oxidizing agents and metal catalysts [4-18]. In particular, $\mathrm{Cu}$-based coordination compounds represent an interesting class of catalysts capable of functionalizing diverse $\mathrm{C}-\mathrm{H}$ bonds [19-22], including those in rather inert substrates such as 
alkanes [1,8,20-28]. In fact, various copper enzymes are known to act as biocatalysts for the oxidative functionalization of organic substrates [20-22]. Although a plethora of bioinspired copper systems were tested for the oxidation of hydrocarbons, there are still a few drawbacks concerning their catalytic application, including the design and preparation of complex and costly ligands, among others $[8,20-22]$.

An interesting approach regarding the preparation of $\mathrm{Cu}$-complex catalysts consists of the usage of commercially available, water-soluble, nontoxic, and multifunctional ligands. One very interesting example of such ligands concerns a trifunctional aminoalcohol sulfonic acid, namely $\mathrm{N}, \mathrm{N}$-bis(2-hydroxyethyl)-2-aminoethanesulfonic acid $\left(\mathrm{H}_{3}\right.$ bes, Scheme 1). Although $\mathrm{H}_{3}$ bes is a very common biobuffer in biochemical research [29,30], its use in catalysis and coordination chemistry remains little explored [31-33]. Due to its structure with three different functionalities (tertiary amine, alcohol, and sulfonic acid groups), versatile multidentate nature, stability, and aqueous solubility, we selected $\mathrm{H}_{3}$ bes as a main building block in the present work.

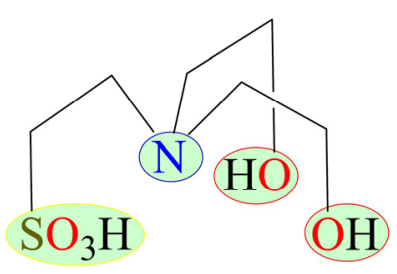

Scheme 1. Formula of $N, N$-bis(2-hydroxyethyl)-2-aminoethanesulfonic acid $\left(\mathrm{H}_{3}\right.$ bes) highlighting three types of functional groups $\left(-\mathrm{N},-\mathrm{OH},-\mathrm{SO}_{3} \mathrm{H}\right)$.

Hence, the principal goals of this study consisted of (A) the preparation and characterization of new multicopper(II) coordination compounds using $\mathrm{H}_{3}$ bes as a primary $\mathrm{N}$, $\mathrm{O}$-ligand source, and (B) the catalytic application of the obtained compounds in oxidation and carboxylation of alkanes (cycloalkanes and propane) to form value-added products (alcohols, ketones, carboxylic acids). Herein we report self-assembly generation, full characterization, X-ray crystal structures, and application in homogeneous catalysis of three novel tetracopper coordination compounds, namely $\left[\mathrm{Cu}_{4}(\mu \text {-Hbes })_{3}\left(\mu-\mathrm{H}_{2}\right.\right.$ bes $)(\mu-$ ba) $\left.)\right] \cdot 2 \mathrm{H}_{2} \mathrm{O}(\mathbf{1}),\left[\mathrm{Cu}_{4}(\mu \text {-Hbes })_{3}\left(\mu-\mathrm{H}_{2}\right.\right.$ bes $)(\mu$-fhba $\left.)\right] \cdot 2 \mathrm{H}_{2} \mathrm{O}(2)$, and $\left[\mathrm{Cu}_{4}(\mu \text {-Hbes })_{3}\left(\mu-\mathrm{H}_{2}\right.\right.$ bes $)(\mu$-thba) $] \cdot 2 \mathrm{H}_{2} \mathrm{O}(3)$, derived from $\mathrm{H}_{3}$ bes and various benzene carboxylic acids (benzoic (Hba), 4-hydroxybenzoic (Hfba), or 3-hydroxybenzoic (Hthba) acid). The effects of different reaction parameters, as well as selectivity and mechanistic features, were studied and discussed in detail.

\section{Results and Discussion}

\subsection{Synthesis of Compounds $\mathbf{1}-\mathbf{3}$}

Tetracopper(II) complexes 1-3 were obtained using a self-assembly synthetic procedure, in $\mathrm{H}_{2} \mathrm{O} / \mathrm{MeCN}$ at $\sim 25^{\circ} \mathrm{C}$ and under aerobic conditions. This method consists of the combination of copper nitrate(II) with $\mathrm{H}_{3}$ bes as a principal building block and benzoic acid (Hba, Hfhba, or Hthba for 1-3, respectively) as a supporting ligand, and ammonia for alkalization of the obtained reaction mixture. This led to a generation, via a self-assembly process, of discrete complexes $\left[\mathrm{Cu}_{4}(\mu \text {-Hbes })_{3}\left(\mu-\mathrm{H}_{2}\right.\right.$ bes $)(\mu$-ba) $] \cdot 2 \mathrm{H}_{2} \mathrm{O}(\mathbf{1}),\left[\mathrm{Cu}_{4}(\mu \text {-Hbes })_{3}\left(\mu-\mathrm{H}_{2}\right.\right.$ bes $)(\mu$-fhba) $] \cdot 2 \mathrm{H}_{2} \mathrm{O}(2)$, and $\left[\mathrm{Cu}_{4}(\mu \text {-Hbes })_{3}\left(\mu-\mathrm{H}_{2}\right.\right.$ bes $)(\mu$-thba) $] \cdot 2 \mathrm{H}_{2} \mathrm{O}(3)$, which slowly crystallized from the reaction mixture. These compounds were obtained as green microcrystals (including those of $X$-ray quality) and then analyzed by elemental analysis, ESI-MS, FTIR spectroscopy, and single-crystal X-ray diffraction (Figure 1 and Figure S1, Supplementary Materials). Discussion of IR and ESI-MS data is given in the Supplementary Materials (Figures S2-S7). 


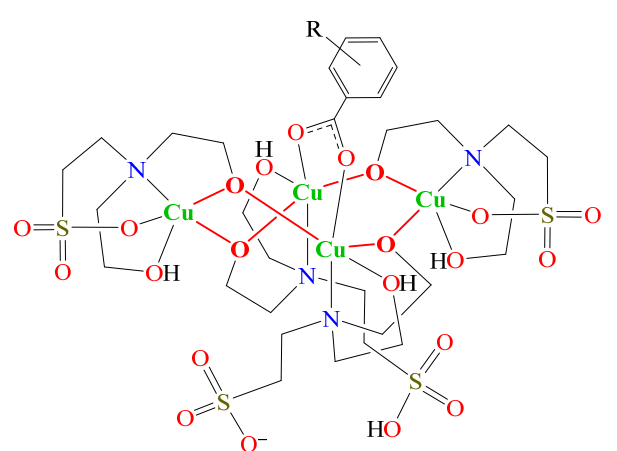

(a)

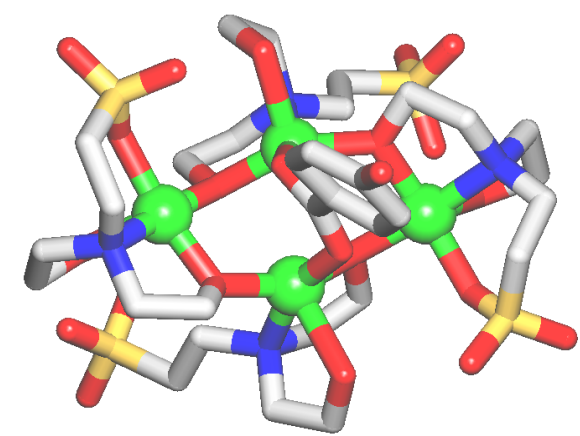

(b)

Figure 1. (a) General formula of 1-3; $\mathrm{R}=\mathrm{H}$ (1), 4-OH (2), and 3-OH (3). (b) Crystal structure of 2 (representative example); $\mathrm{H}$ atoms are omitted for clarity; $\mathrm{Cu}$ (green balls), $\mathrm{O}$ (red), $\mathrm{N}$ (blue), $\mathrm{S}$ (yellow), C (gray).

\subsection{Structural Description}

Crystal structures of 1-3 are essentially similar and are composed of the neutral discrete tetracopper(II) molecular units with a general formula $\left[\mathrm{Cu}_{4}(\mu-\mathrm{Hbes})_{3}\left(\mu-\mathrm{H}_{2}\right.\right.$ bes $\left.)(\mu-\mathrm{L})\right]\left(\mathrm{L}=\mathrm{ba}^{-}(\mathbf{1})\right.$, $\mathrm{fhba}^{-}(2)$, and thba ${ }^{-}$(3)) (Figure 1a and Figure S1, Supplementary Materials). As an example, the structure of compound 2 is described in detail (Figure $1 \mathrm{~b}$ ).

In 2, a tetracopper(II) unit is composed of two "central" Cu1/Cu3 and two "side" Cu2/Cu4 atoms, four bridging aminoalcoholate sulfonate ligands (three $\mu-\mathrm{Hbes}^{2-}$ and one $\mu-\mathrm{H}_{2} \mathrm{bes}^{-}$), and one $\mu$-4-hydroxybenzoate ${ }^{-}$linker. The "central" $\mathrm{Cu} 1 / \mathrm{Cu} 3$ atoms are five-coordinate atoms and possess a distorted $\mathrm{CuNO}_{4}$ square-pyramidal environment, which is taken by three oxygen and one nitrogen donors of the $\mu-\mathrm{Hbes}^{2-} / \mu-\mathrm{H}_{2}$ bes $^{-}$moieties (Cu-O 1.931(7)-2.333(9), $\mathrm{Cu}-\mathrm{N}$ 2.063(9)-2.098(11) $\AA$ ) and an O atom of $\mu$-fhba ${ }^{-}$linker ( $\left.\mathrm{Cu}-\mathrm{O} 2.001(9)-2.029(9) \AA\right)$. The "side" $\mathrm{Cu} 2 / \mathrm{Cu} 4$ centers are also five-coordinate atoms and feature a distorted $\mathrm{CuNO}_{4}$ square-pyramidal geometry. It is formed by four oxygen and one nitrogen donors of $\mu-\mathrm{Hbes}^{2-}$ ligands (Cu-O 1.899(7)-2.336(8), $\mathrm{Cu}-\mathrm{N}$ 2.003(9)-2.062(9) $\AA$ ). These distances are comparable to those reported for related types of $\mathrm{Cu}$ derivatives [31-33]. The carboxylate group of the $\mu$-fhba ${ }^{-}$linker adopts a bridging bidentate mode and interconnects the $\mathrm{Cu} 1 / \mathrm{Cu} 3$ centers with a Cu1 $\cdots \mathrm{Cu} 3$ separation of 3.054(2) $\AA$. The $\mu-\mathrm{Hbes}^{2-} / \mu-\mathrm{H}_{2} \mathrm{bes}^{-}$moieties that act as chelating ligands to the "central" $\mathrm{Cu} 1 / \mathrm{Cu} 3$ atoms have a sulfonic acid group uncoordinated, whereas the $\mu-\mathrm{Hbes}^{2-}$ ligands that chelate to the "side" $\mathrm{Cu} 2$ atoms have all "arms" coordinated.

Within the $\mathrm{Cu}_{4}(\mu \text {-Hbes })_{3}\left(\mu-\mathrm{H}_{2}\right.$ bes $)(\mu$-fhba) molecular unit, the $\mathrm{Cu}$ centers are arranged into a cyclic $\mathrm{Cu}_{4}(\mu-\mathrm{O})_{4}(\mu-\mathrm{COO})$ core with a longest $\mathrm{Cu} 2 \cdots \mathrm{Cu} 4$ separation of 5.876(2) $\AA$. The $\mathrm{Cu}_{4}$ unit is additionally stabilized by means of the $\mathrm{O}-\mathrm{H} \cdots \mathrm{O}$ intramolecular hydrogen bonds between $-\mathrm{SO}_{3} \mathrm{H}$ or $-\mathrm{OH}$ functionalities of $\mu-\mathrm{Hbes}^{2-} / \mu-\mathrm{H}_{2}$ bes $^{-}$and the $\mathrm{O}$ atoms of adjacent aminoalcoholate moieties. Furthermore, the intermolecular $\mathrm{H}$-bonds between the $\mathrm{Cu}_{4}(\mu-\mathrm{Hbes})_{3}\left(\mu-\mathrm{H}_{2}\right.$ bes $)(\mu$-fhba) units and water molecules of crystallization give rise to a structure extension (zero dimensions to three dimensions $(0 \mathrm{D} \rightarrow 3 \mathrm{D}))$ forming a 3D H-bonded network.

\subsection{Mild Catalytic Oxidation of Cycloalkanes}

In pursuit of our prior research on alkane functionalization [23-26,32-37], we tested the obtained tetracopper(II) complexes 1-3 as catalysts in the homogeneous oxidation of cyclohexane and related cycloalkanes to generate cycloalkyl hydroperoxides as primary products and then alcohols and ketones as final products (Scheme 2).

The oxidation of $\mathrm{C}_{6} \mathrm{H}_{12}$ was studied as a model reaction due to the relevance of cyclohexanol and cyclohexanone to nylon production [38-41]. Typical reactions were performed in acetonitrile/water medium at $50{ }^{\circ} \mathrm{C}$ and under atmospheric pressure, using hydrogen peroxide ( $50 \%$ in water) as a green oxidant and a small quantity of trifluoroacetic acid (TFA) as a promoter [13-15]. Compounds 1-3 
catalyze the cyclohexane oxidation with hydrogen peroxide, resulting in the $12-16 \%$ total yields of cyclohexanol and cyclohexanone as final products (Figure 2). Hereinafter, the product yields are relative to substrate ((moles of alcohol and ketone per mol of substrate) $\times 100 \%)$, and were obtained after the treatment of the reaction mixtures with triphenylphosphine for reduction of peroxides (cyclohexyl hydroperoxide to cyclohexanol and $\mathrm{H}_{2} \mathrm{O}_{2}$ to water). The formation of cyclohexyl hydroperoxide as a primary (intermediate) product was confirmed following a method developed by Shul'pin [5,15], which is based on the GC (gas chromatography) analysis of the reaction mixtures before and after the treatment with solid $\mathrm{PPh}_{3}$. The maximum yield is attained after 90-120 min of the reaction. In some cases, a slight yield drop was observed due to an overoxidation that might occur at a prolonged reaction time. Influence of different reaction parameters was studied and is described below.

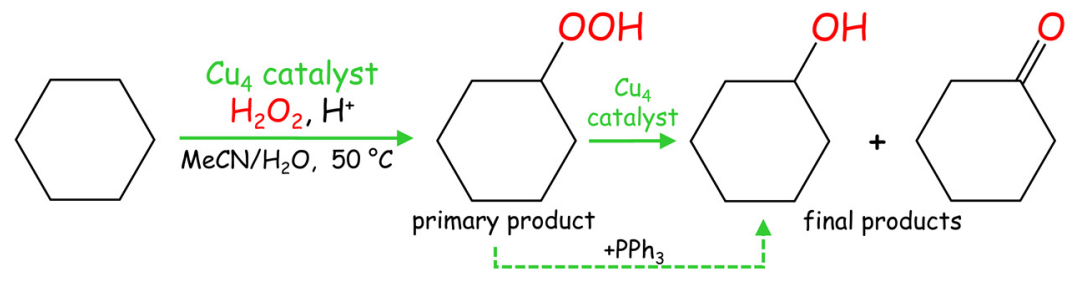

Scheme 2. Mild Cu-catalyzed oxidation of cyclohexane (model cycloalkane substrate).

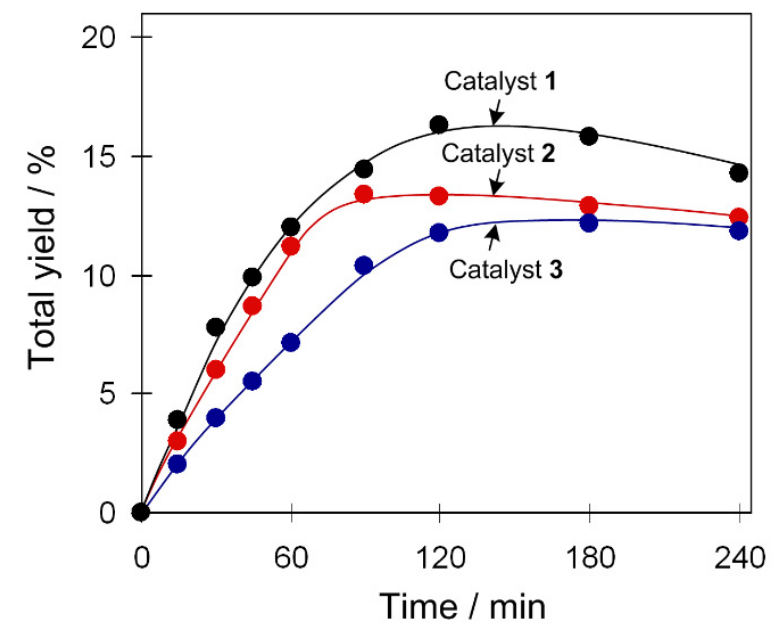

Figure 2. Accumulation of products (cyclohexanol and cyclohexanone total yield) in Cu-catalyzed $\mathrm{C}_{6} \mathrm{H}_{12}$ oxidation with $\mathrm{H}_{2} \mathrm{O}_{2}$. Conditions: catalyst 1-3 $(2.5 \mu \mathrm{mol}), \mathrm{C}_{6} \mathrm{H}_{12}(1 \mathrm{mmol})$, trifluoroacetic acid (TFA; $50 \mu \mathrm{mol}$ ), $\mathrm{H}_{2} \mathrm{O}_{2}$ (5 mmol), $\mathrm{CH}_{3} \mathrm{CN}$ (up to $2.5 \mathrm{~mL}$ of total volume), $50{ }^{\circ} \mathrm{C}$.

\subsubsection{Acid Promoter Effect}

Since the $\mathrm{Cu}$-catalyzed oxidation reactions require a minor quantity of an acid promoter, we tested the promoting effect of various acids, namely trifluoroacetic (TFA), nitric, sulfuric, or hydrochloric acids (Figure 3 and Figure S8, Supplementary Materials). According to a literature background $[15,40]$, the function of an acid promoter might consist of the following: (A) activation of catalyst via unsaturation of copper centers by protonation of ligands; (B) facilitation of proton transfer steps; (C) increase of the reaction rate of oxidation; (D) facilitation of the formation of peroxo complexes; (E) increase of hydrogen peroxide reactivity; (F) suppressing a decomposition of $\mathrm{H}_{2} \mathrm{O}_{2}$ to $\mathrm{H}_{2} \mathrm{O}$ and $\mathrm{O}_{2}$ (eventual catalase activity of catalyst can be suppressed in the presence of acid).

Kinetic curves of product accumulation in the cyclohexane oxidation catalyzed by 2 in the systems containing various acid promoters are shown in Figure 3. The oxidation is exceptionally fast when using $\mathrm{HCl}$ as a promoter, leading to a $16 \%$ yield of products already after $15 \mathrm{~min}$ of reaction (turnover frequency: TOF $\sim 250 \mathrm{~h}^{-1}$ ). Such a remarkable effect of hydrochloric acid on the reaction rate of cyclohexane oxidation was previously observed in other systems and can be associated with the 
participation of $\mathrm{Cl}^{-}$ions in the generation of catalytically active species bearing bridging or terminal chloride ligands [8]. TFA, $\mathrm{HNO}_{3}$, and $\mathrm{H}_{2} \mathrm{SO}_{4}$ exhibit a slightly weaker promoting behavior with total yields of $14-11 \%$, which are achieved at more prolonged reaction times relative to a system operating with $\mathrm{HCl}$. We also studied the promoting effects of different acids for catalysts $\mathbf{1}$ and $\mathbf{3}$ which reveal a behavior similar to 2 (Figure S8, Supplementary Materials).

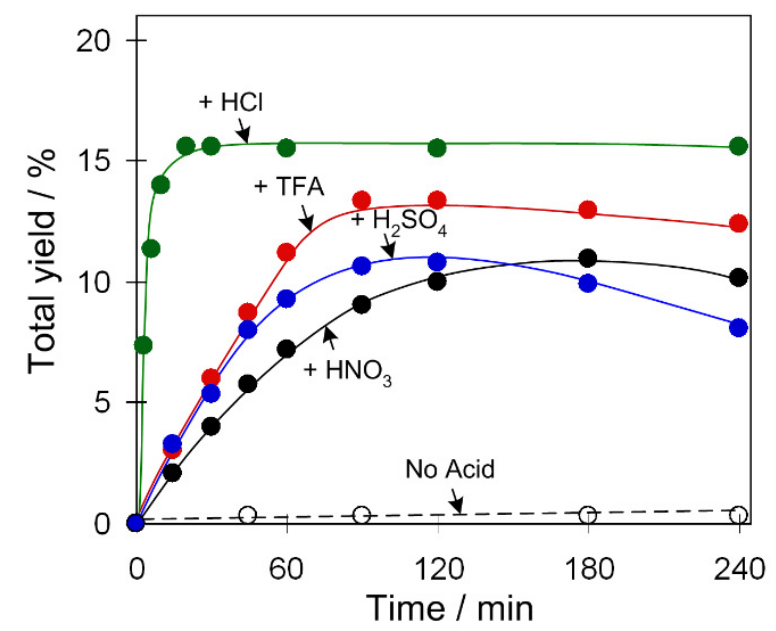

Figure 3. Effect of acid promoter type on the total yield of products (cyclohexanol and cyclohexanone) in $\mathrm{C}_{6} \mathrm{H}_{12}$ oxidation with $\mathrm{H}_{2} \mathrm{O}_{2}$. Conditions: catalyst $2(2.5 \mu \mathrm{mol}), \mathrm{C}_{6} \mathrm{H}_{12}(1 \mathrm{mmol})$, acid $(50 \mu \mathrm{mol})$, $\mathrm{H}_{2} \mathrm{O}_{2}$ (5 mmol), $\mathrm{CH}_{3} \mathrm{CN}$ solvent (up to $2.5 \mathrm{~mL}$ of the total reaction volume), $50{ }^{\circ} \mathrm{C}$.

An influence of the TFA amount was also investigated for catalyst 2 (Figure 4) that is barely active without an acid promoter. However, total yield of products gradually grew upon elevating the amount of acid promoter up to 20 equivalents relative to the catalyst.

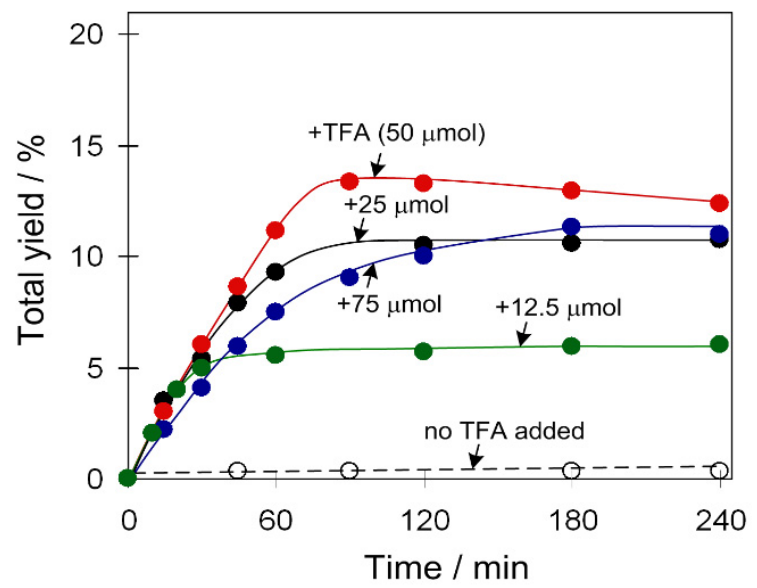

Figure 4. Effect of TFA amount on total product yield (cyclohexanol and cyclohexanone) in the $\mathrm{C}_{6} \mathrm{H}_{12}$ oxidation with $\mathrm{H}_{2} \mathrm{O}_{2}$. Conditions: catalyst $2(2.5 \mu \mathrm{mol}), \mathrm{C}_{6} \mathrm{H}_{12}(1 \mathrm{mmol})$, TFA $(0-75 \mu \mathrm{mol}), \mathrm{H}_{2} \mathrm{O}_{2}$ (5 mmol), $\mathrm{CH}_{3} \mathrm{CN}$ (up to $2.5 \mathrm{~mL}$ of the total reaction volume), $50{ }^{\circ} \mathrm{C}$.

\subsubsection{Effect of Catalyst Amount}

We also studied the influence of the amount of catalyst 2 on the yield and $W_{0}$ (maximum initial reaction rate) in the oxidation of cyclohexane (Figure 5). Blank experiments revealed that the cyclohexane oxidation products are not formed unless copper catalyst is added. An increase of the catalyst amount from 1.25 to $5 \mu \mathrm{mol}$ results in an increase of both $W_{0}$ and total yield of products (Figure 5a). The highest yield of $17 \%$ was obtained when using $5 \mu \mathrm{mol}$ of catalyst. A linear trend between $W_{0}$ and the amount of catalyst was observed (Figure $5 \mathrm{~b}$ ), suggesting kinetics of the first order 
and supporting an eventual participation of a single type of copper species in a rate-limiting step of the oxidation reaction.

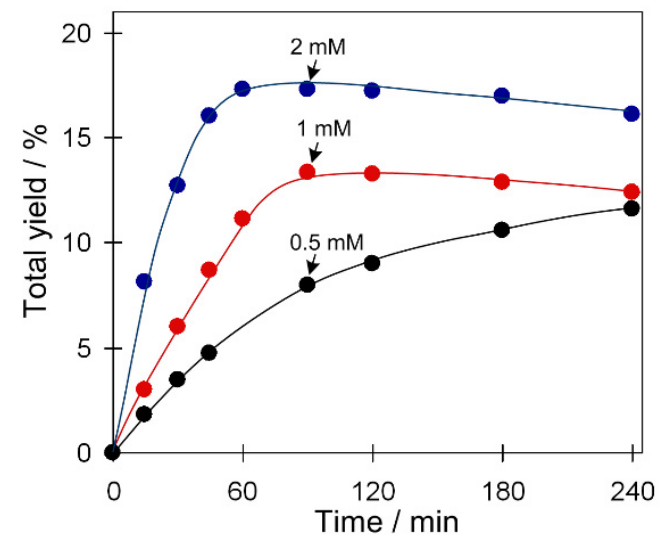

(a)

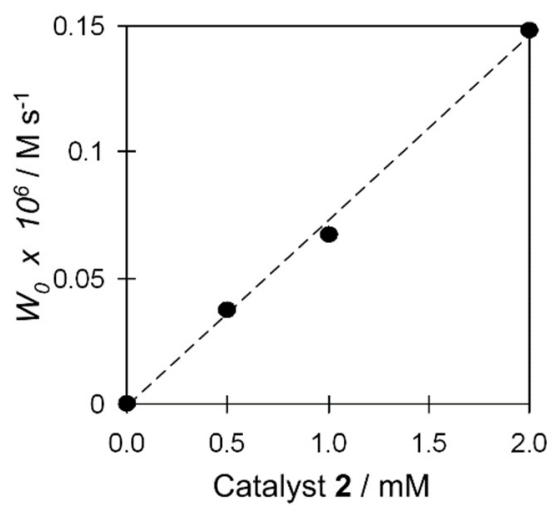

(b)

Figure 5. Effect of catalyst loading on (a) total product yield (cyclohexanol and cyclohexanone), and (b) $W_{0}$ (initial reaction rate) in the $\mathrm{C}_{6} \mathrm{H}_{12}$ oxidation with $\mathrm{H}_{2} \mathrm{O}_{2}$. Conditions: catalyst $2(1.25-5 \mu \mathrm{mol})$, $\mathrm{C}_{6} \mathrm{H}_{12}(1 \mathrm{mmol}), \mathrm{TFA}(50 \mu \mathrm{mol}), \mathrm{H}_{2} \mathrm{O}_{2}(5 \mathrm{mmol}), \mathrm{CH}_{3} \mathrm{CN}$ (up to $2.5 \mathrm{~mL}$ of the total reaction volume), $50{ }^{\circ} \mathrm{C}$.

\subsubsection{Substrate Scope}

Apart from cyclohexane, oxidation of other cycloalkane substrates was also explored (Table 1, Figure 6 and Figure S9, Supplementary Materials). For catalyst 2, more reactive substrates are cycloheptane and cyclooctane, which lead to the maximum total yields of 26 and $20 \%$, respectively. In comparison, the oxidation of cyclohexane and cyclopentane is less efficient (13-9\% product yield). This might be influenced by the stability of formed radicals (cycloalkyl radicals) that increases with the ring size. Moreover, cyclopentane is rather volatile (boiling point (bp): $49^{\circ} \mathrm{C}$ ) and, at typical reaction conditions $\left(50^{\circ} \mathrm{C}\right)$, can partially be present in the gas phase; this may explain its lower reactivity. Such a trend of substrate reactivity is also observed for catalytic systems based on $\mathbf{1}$ or $\mathbf{3}$ (Table 1, Figure S9, Supplementary Materials).

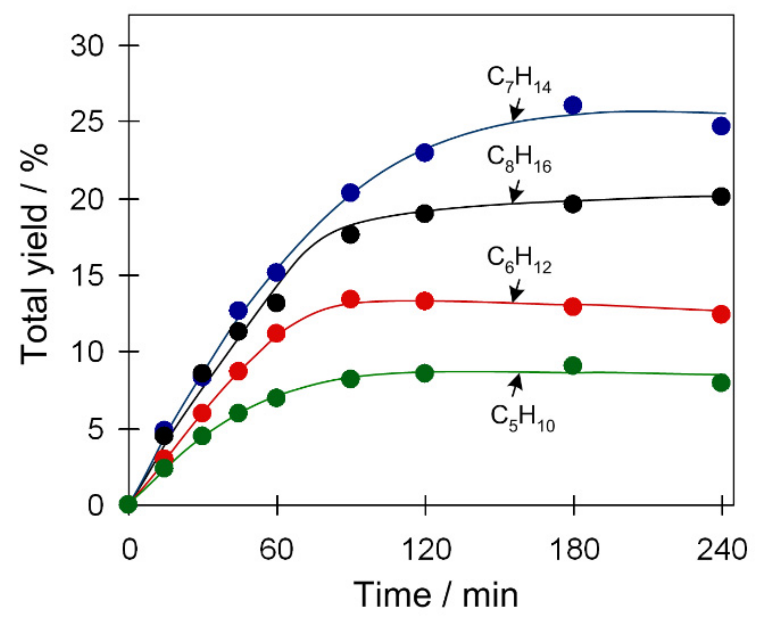

Figure 6. Substrate scope in the cycloalkane oxidation to cyclic alcohols and ketones (total product yield vs. time) with $\mathrm{H}_{2} \mathrm{O}_{2}$. Conditions: catalyst $2(2.5 \mu \mathrm{mol})$, cycloalkane $(1 \mathrm{mmol})$, TFA (50 $\left.\mu \mathrm{mol}\right)$, $\mathrm{H}_{2} \mathrm{O}_{2}$ (5 mmol), $\mathrm{CH}_{3} \mathrm{CN}$ (up to $2.5 \mathrm{~mL}$ of the total reaction volume), $50{ }^{\circ} \mathrm{C}$. 
Table 1. Substrate scope in cycloalkane oxidation with $\mathrm{H}_{2} \mathrm{O}_{2}$ catalyzed by $1-3^{\text {a }}$.

\begin{tabular}{lcccc}
\hline \multirow{2}{*}{\begin{tabular}{c}
\multirow{2}{*}{ Substrate } \\
Cyclopentane
\end{tabular}} & Ketone & Total \\
\cline { 3 - 5 } & $\mathbf{1}$ & 6.1 & 7.2 & 13.3 \\
& $\mathbf{2}$ & 4.0 & 5.0 & 9.0 \\
& $\mathbf{3}$ & 2.6 & 4.3 & 6.9 \\
\hline Cyclohexane & $\mathbf{1}$ & 8.9 & 6.9 & 15.8 \\
& $\mathbf{2}$ & 7.6 & 5.3 & 12.9 \\
& $\mathbf{3}$ & 7.8 & 4.3 & 12.1 \\
\hline Cycloheptane & $\mathbf{1}$ & 13.1 & 12.8 & 25.9 \\
& $\mathbf{2}$ & 13.4 & 12.6 & 26.0 \\
& $\mathbf{3}$ & 9.6 & 13.2 & 22.8 \\
\hline Cyclooctane & $\mathbf{1}$ & 9.7 & 16.3 & 26.0 \\
& $\mathbf{2}$ & 6.5 & 13.1 & 19.6 \\
& $\mathbf{3}$ & 6.5 & 13.2 & 19.6 \\
\hline
\end{tabular}

a Conditions: catalyst 1-3 $(2.5 \mu \mathrm{mol})$, cycloalkane (1 mmol), trifluoroacetic acid (TFA; $50 \mu \mathrm{mol}), \mathrm{H}_{2} \mathrm{O}_{2}(5 \mathrm{mmol})$, $\mathrm{CH}_{3} \mathrm{CN}$ (up to $2.5 \mathrm{~mL}$ of the total reaction volume), $3 \mathrm{~h}, 50^{\circ} \mathrm{C}$. ${ }^{\mathrm{b}}$ Yields are relative to hydrocarbon substrate: (moles of product per mol of cycloalkane) $\times 100 \%$.

\subsubsection{Effect of Substrate and Oxidant Amount}

In cyclohexane oxidation catalyzed by 2 (Figure S10, Supplementary Materials), the reaction efficiency practically does not depend on the substrate amount within the studied range of loadings $\left(0.5-2 \mathrm{mmol} \mathrm{C}_{6} \mathrm{H}_{12}\right)$. In contrast, the amount of oxidant has a significant effect (Figure 7) and an excess of hydrogen peroxide is required for efficient oxidation of cyclohexane. An increase of the $\mathrm{H}_{2} \mathrm{O}_{2}$ amount from 1.5 to $7.5 \mathrm{mmol}$ results in the growth of $W_{0}$ (initial reaction rate) and product yield. Furthermore, higher loadings of $\mathrm{H}_{2} \mathrm{O}_{2}$ (up to $7.5 \mathrm{mmol}$ ) may lead to a yield drop due to the overoxidation at prolonged reaction times. The $W_{0}$ linearly depends on the amount of hydrogen peroxide (Figure $7 \mathrm{~b}$ ), suggesting reaction kinetics of the first order for the oxidant.

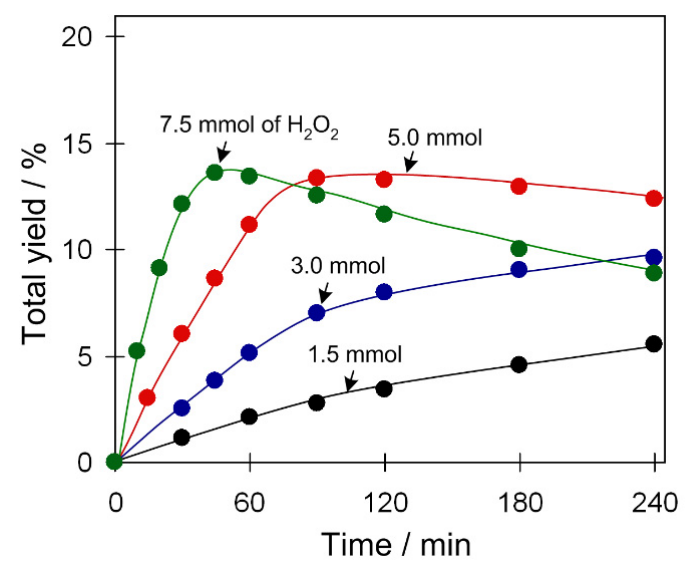

(a)

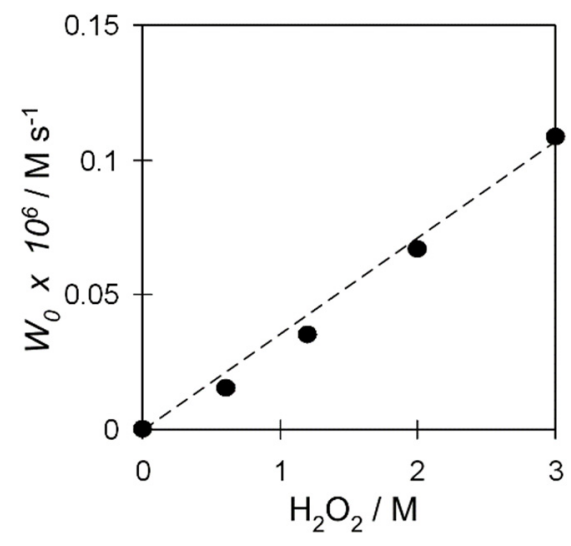

(b)

Figure 7. Effect of the $\mathrm{H}_{2} \mathrm{O}_{2}$ amount on (a) total product yield (cyclohexanol and cyclohexanone), and (b) $W_{0}$ in $\mathrm{C}_{6} \mathrm{H}_{12}$ oxidation with $\mathrm{H}_{2} \mathrm{O}_{2}$. Conditions: catalyst $2(2.5 \mu \mathrm{mol}), \mathrm{C}_{6} \mathrm{H}_{12}(1 \mathrm{mmol})$, TFA (50 $\mu \mathrm{mol}), \mathrm{H}_{2} \mathrm{O}_{2}(1.5-7.5 \mathrm{mmol}), \mathrm{CH}_{3} \mathrm{CN}$ (up to $2.5 \mathrm{~mL}$ of total reaction volume), $50{ }^{\circ} \mathrm{C}$.

\subsubsection{Effect of Water}

Recently, we reported an unexpected acceleration effect of $\mathrm{H}_{2} \mathrm{O}$ on cyclohexane oxidation catalyzed by other $\mathrm{Cu}$ catalytic systems $[23,24]$. Aiming at understanding whether $\mathrm{H}_{2} \mathrm{O}$ plays any role in the present $\mathrm{Cu}_{4}$ catalytic systems, we investigated the influence of water quantity in the system 
on both the $W_{0}$ (maximum initial reaction rate) and product yield values in the $\mathrm{C}_{6} \mathrm{H}_{12}$ oxidation in the presence of catalyst 2 (Figure 8). Some water quantity $(4.0 \mathrm{M}$ ) is already present in the reaction system that comes from the aqueous $50 \% \mathrm{H}_{2} \mathrm{O}_{2}$. Addition of an extra portion of $\mathrm{H}_{2} \mathrm{O}(200 \mu \mathrm{L}, 4.4 \mathrm{M}$; $8.4 \mathrm{M} \mathrm{H}_{2} \mathrm{O}$ total) into the reaction mixture results in an increase of the initial reaction rate $W_{0}$ while not affecting the maximum yield of products. Addition of a double amount of water $(400 \mu \mathrm{L}, 8.4 \mathrm{M}$; $12.8 \mathrm{M} \mathrm{H}_{2} \mathrm{O}$ total) leads to further acceleration of $W_{0}$ which, however, is accompanied by the decrease of total yield. The $W_{0}$ values reveal a linear trend in the concentration of water within a studied range of concentrations (Figure 8b), thus suggesting an involvement of $\mathrm{H}_{2} \mathrm{O}$ in a rate-limiting step of the reaction. Such a promoting $\mathrm{H}_{2} \mathrm{O}$ behavior opens up a possibility of using the diluted $\mathrm{H}_{2} \mathrm{O}_{2}$ solutions (generated in situ) for cycloalkane oxidation.

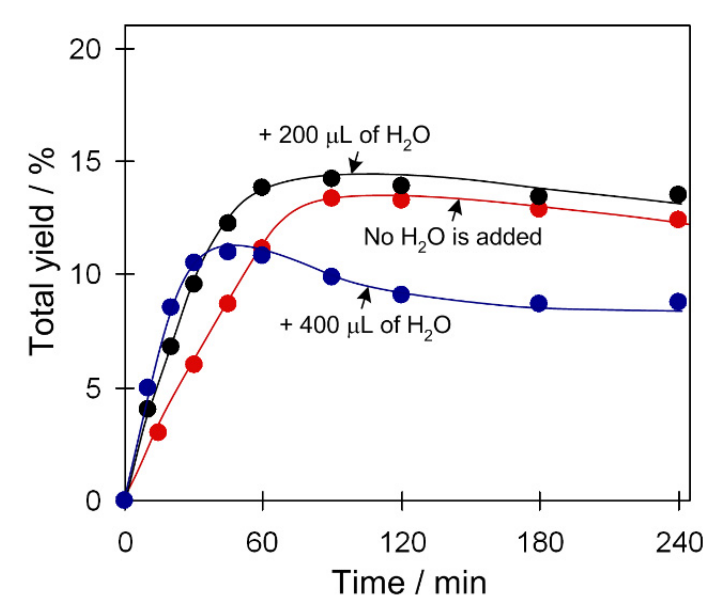

(a)

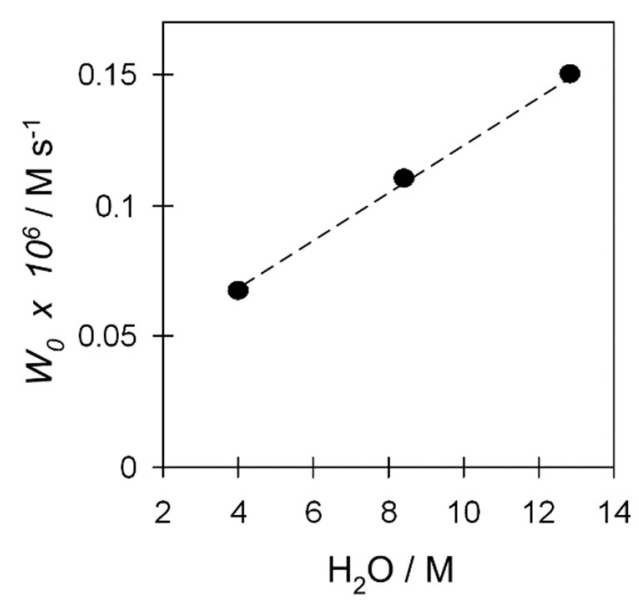

(b)

Figure 8. Effect of $\mathrm{H}_{2} \mathrm{O}$ amount on (a) product yield (cyclohexanol and cyclohexanone), and (b) $W_{0}$ in $\mathrm{C}_{6} \mathrm{H}_{12}$ oxidation with $\mathrm{H}_{2} \mathrm{O}_{2}$. Conditions: catalyst $2(2.5 \mu \mathrm{mol}), \mathrm{C}_{6} \mathrm{H}_{12}(1 \mathrm{mmol})$, TFA $(50 \mu \mathrm{mol}), \mathrm{H}_{2} \mathrm{O}_{2}$ (5 mmol), added $\mathrm{H}_{2} \mathrm{O}(200 ; 400 \mu \mathrm{L}), \mathrm{CH}_{3} \mathrm{CN}$ (up to $2.5 \mathrm{~mL}$ of total reaction volume), $50{ }^{\circ} \mathrm{C}$.

\subsection{Mild Cu-Catalyzed Oxidation of Propane}

Development of the direct oxidation of propane constitutes a very promising approach in catalysis due to the abundance of this hydrocarbon as a $\mathrm{C}_{3}$ feedstock for the generation of value-added oxidation products [1,2]. Hence, catalytic performance of compounds 1-3 was also evaluated the in the propane oxidation with $\mathrm{H}_{2} \mathrm{O}_{2}$ under mild conditions, resulting in a mixture of isopropanol, acetone, $n$-propanol, and propanal (Scheme 3, Table 2).

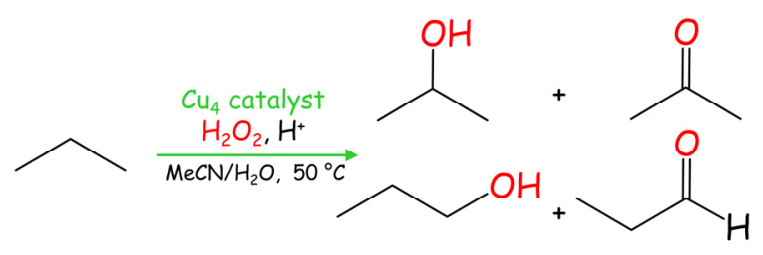

Scheme 3. Mild Cu-catalyzed oxidation of propane.

All catalysts 1-3 exhibit a comparable level of activity regarding the total product yield, which is in the $7-9 \%$ range (based on propane). As expected, the oxidation at the secondary C(2) atom is preferable, resulting in the generation of $i$-propanol and acetone as major products, due to an easier activation of the secondary carbon in propane in comparison with the two primary ones. Thus, $n$-propanol and propanal are formed in minor quantities (Table 2). Despite not being very high, such a level of total yields (up to $9 \%$ ) in propane oxidation can be considered as significant given the high inertness of 
propane, its low solubility in the reaction medium, and the mild reaction conditions applied $\left(50{ }^{\circ} \mathrm{C}\right.$, low-pressure reaction).

Table 2. Mild propane oxidation with hydrogen peroxide catalyzed by $1-3^{a}$.

\begin{tabular}{ccccccc}
\hline \multirow{2}{*}{ Catalyst } & \multicolumn{5}{c}{ Product Yield, $\mathbf{\%}^{\mathbf{b}}$} & \multirow{2}{*}{ TON $^{\mathbf{c}}$} \\
\cline { 2 - 6 } & $\boldsymbol{i}$-Propanol & Acetone & $\boldsymbol{n}$-Propanol & Propanal & Total & \\
\hline $\mathbf{1}$ & 1.8 & 3.4 & 1.1 & 0.8 & 7.1 & 60 \\
$\mathbf{2}$ & 2.7 & 4.2 & 1.4 & 0.9 & 9.2 & 77 \\
$\mathbf{3}$ & 2.8 & 3.4 & 1.2 & 0.6 & 8.0 & 67 \\
\hline
\end{tabular}

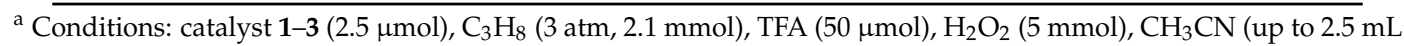
of total reaction volume), $4 \mathrm{~h}, 50{ }^{\circ} \mathrm{C}$, in stainless-steel autoclave of 20 -mL capacity. ${ }^{\mathrm{b}}$ Yields are based on propane, (moles of product per mol of propane) $\times 100 \%{ }^{c}{ }^{\mathrm{c}} \mathrm{TON}$, moles of product per mol of catalyst.

\subsection{Selectivity Parameters and Mechanistic Considerations in Alkane Oxidation}

Catalysts 1-3 were also tested in oxidation reactions of other alkanes, including a linear alkane ( $n$-heptane), polycyclic alkane (adamantane), and cycloalkanes with methyl functionality (methylcyclohexane, cis-dimethylcyclohexane), aiming at establishing various selectivity parameters (Table 3) and getting additional mechanistic information. Hence, $n$-heptane oxidation undergoes with no regio-preference to a secondary $C$ atom, showing the $C(1): C(2): C(3): C(4)$ regioselectivity parameters of 1:4:5:8 (for 1), 1:5:5:7 (for 2), and 1:5:5:8 (for 3). Oxidation of methylcyclohexane proceeds with a moderate bond selectivity $1^{\circ}: 2^{\circ}: 3^{\circ}$ of $1: 5: 19,1: 5: 14$, and $1: 6: 15$ for catalysts $1-3$, respectively. For the oxidation of adamantane, the $2^{\circ}: 3^{\circ}$ bond selectivity parameter is close to $1: 4$ for all the catalysts (Table 3 ). Oxidation of cis-dimethylcyclohexane provides the information about stereoselectivity through the determination trans/cis ratio between the isomeric tertiary alcohol products. The observed trans/cis values are $0.9,0.8$, and 1.1 for $\mathbf{1}-\mathbf{3}$, respectively; these suggest that the reactions are non-stereoselective.

Table 3. Selectivity parameters in the oxidation of alkanes with $\mathrm{H}_{2} \mathrm{O}_{2}$ catalyzed by $1-3{ }^{\text {a }}$.

\begin{tabular}{|c|c|c|c|}
\hline \multirow{2}{*}{ Selectivity Parameter } & \multicolumn{3}{|c|}{ Catalyst } \\
\hline & 1 & 2 & 3 \\
\hline Regioselectivity & & & \\
\hline $\mathrm{C}(1): \mathrm{C}(2): \mathrm{C}(3): \mathrm{C}(4)(n \text {-heptane })^{b}$ & $1: 4: 5: 8$ & $1: 5: 5: 7$ & $1: 5: 5: 8$ \\
\hline Bond selectivity & & & \\
\hline $1^{\circ}: 2^{\circ}: 3^{\circ}$ (methylcyclohexane) $^{c}$ & $1: 5: 15$ & $1: 5: 19$ & $1: 6: 13$ \\
\hline $2^{\circ}: 3^{\circ}(\text { adamantane })^{d}$ & $1: 4$ & $1: 3.6$ & $1: 3.6$ \\
\hline Stereoselectivity & & & \\
\hline trans / cis (cis-dimethylcyclohexane) ${ }^{\mathrm{e}}$ & 0.9 & 0.8 & 1.1 \\
\hline
\end{tabular}

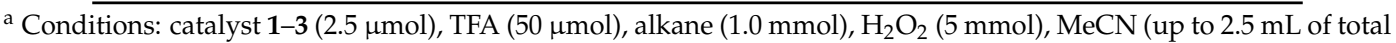
volume), $3 \mathrm{~h}, 50^{\circ} \mathrm{C}$. Oxidation reactions result in the formation of alkyl hydroperoxides as primary products and alcohols and ketones/aldehydes as final products. Herein, all selectivity parameters were calculated on the basis of the molar ratios of the alcohol product isomers after the treatment of the reaction mixtures with solid $\mathrm{PPh}_{3}$ (to reduce to alcohols, the alkyl hydroperoxides formed as primary products) followed by normalization (the number of hydrogen atoms at each carbon atom was taken into consideration). ${ }^{b}$ Parameters $C(1): C(2): C(3): C(4)$ refer to the reactivity of hydrogen atoms at $\mathrm{C}(1), \mathrm{C}(2), \mathrm{C}(3)$, and $\mathrm{C}(4)$ atoms of $n-\mathrm{C}_{7} \mathrm{H}_{16} \cdot{ }^{\mathrm{c}}$ Parameters $1^{\circ}: 2^{\circ}: 3^{\circ}$ refer to the reactivity of hydrogen atoms at primary, secondary, and tertiary carbon atoms of methylcyclohexane. ${ }^{\mathrm{d}}$ Parameters $2^{\circ}: 3^{\circ}$ refer to the reactivity of hydrogen atoms at secondary and tertiary carbon atoms of adamantane. ${ }^{\mathrm{e}}$ Parameters trans/cis refer to the ratio of the formed tertiary alcohol isomers with trans and cis orientation of $\mathrm{CH}_{3}$ groups.

The obtained selectivity parameters, the generation of alkyl hydroperoxides as primary intermediate products (detected by Shul'pin's method [5,15]), and the analysis of the relevant literature [1-15] support a radical-type mechanism that involves indiscriminate oxidizing species such as hydroxyl radicals. Hence, we can propose a simplified mechanism for the Cu-catalyzed alkane oxidation with $\mathrm{H}_{2} \mathrm{O}_{2}$. It involves the following steps [8]: (1) formation of $\mathrm{HO}^{\bullet}$ radicals upon the interaction of $\mathrm{H}_{2} \mathrm{O}_{2}$ with $\mathrm{Cu}$ catalyst; (2) reaction of $\mathrm{HO} \bullet$ radicals with alkane, abstracting $\mathrm{H}$ atom 
and forming $\mathrm{R}^{\bullet}$ (alkyl radicals); (3) formation of $\mathrm{ROO}^{\bullet}$ radicals in the reaction of alkyl radicals with $\mathrm{O}_{2} ;(4)$ transformation of $\mathrm{ROO}^{\bullet}$ radicals to $\mathrm{ROOH}$ (alkyl hydroperoxides) as a primary intermediate product; (5) decomposition of $\mathrm{ROOH}$ (via Cu-catalyzed processes), leading to alcohols ( $\mathrm{ROH}$ ) and ketones $\left(\mathrm{R}^{\prime}=\mathrm{O}\right)$ as final oxidation products.

\subsection{Mild Cu-Catalyzed Carboxylation of $\mathrm{C}_{5}-C_{8}$ Cycloalkanes}

In addition to the oxidation reactions, catalysts 1-3 were tested in the single-pot carboxylation of cycloalkanes under mild conditions [8]. This reaction consists of the treatment of $C_{n}$ cycloalkane with a carbonyl source (CO), a hydroxyl source $\left(\mathrm{H}_{2} \mathrm{O}\right)$, and an oxidant (potassium peroxodisulfate) to directly generate a $\mathrm{C}_{\mathrm{n}+1}$ cycloalkane carboxylic acid as the main product (Scheme 4); in addition, cyclic alcohols and ketones are formed as minor oxidation products.

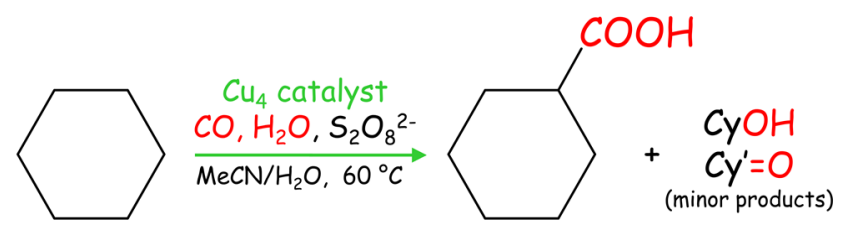

Scheme 4. Single-pot $\mathrm{Cu}$-catalyzed carboxylation of cycloalkanes $\left(C_{n}\right)$ to give cycloalkane carboxylic acids $\left(C_{n+1}\right)$; cyclohexane is shown as a model substrate.

Compounds 1-3 show very high activity (total product yields up to $46 \%$ ) in the carboxylation of cycloalkanes (cyclooctane, cycloheptane, cyclohexane, and cyclopentane) to form cycloalkane carboxylic acid as a main product (Table 4). The catalytic activity of 1-3 is rather similar. In comparison to the oxidation reactions of cycloalkanes with $\mathrm{H}_{2} \mathrm{O}_{2}$, the $\mathrm{Cu}$-catalyzed alkane carboxylation reactions proceed in the absence of an acid promoter.

Table 4. Single-pot Cu-catalyzed carboxylation of cycloalkanes ${ }^{\mathrm{a}}$.

\begin{tabular}{|c|c|c|c|c|c|}
\hline \multirow[b]{2}{*}{ Substrate } & \multirow[b]{2}{*}{ Catalyst } & \multicolumn{4}{|c|}{ Yield (\%) ${ }^{b}$} \\
\hline & & Cycloalkane Carboxylic Acid & Cyclic Ketone & Cyclic Alcohol & Total $^{\mathrm{c}}$ \\
\hline \multirow[t]{3}{*}{ Cyclopentane } & 1 & 30.9 & 3.1 & 0.8 & 34.8 \\
\hline & 2 & 21.0 & 2.7 & 1.1 & 24.8 \\
\hline & 3 & 27.1 & 3.5 & 0.8 & 31.4 \\
\hline \multirow[t]{3}{*}{ Cyclohexane } & 1 & 41.4 & 1.5 & 0.3 & 43.2 \\
\hline & 2 & 42.9 & 2.6 & 0.6 & 46.1 \\
\hline & 3 & 40.0 & 2.4 & 0.5 & 42.9 \\
\hline \multirow[t]{3}{*}{ Cycloheptane } & 1 & 22.5 & 10.9 & 3.6 & 37.0 \\
\hline & 2 & 22.4 & 9.1 & 3.5 & 35.0 \\
\hline & 3 & 27.3 & 10.4 & 3.1 & 40.8 \\
\hline \multirow[t]{3}{*}{ Cyclooctane } & 1 & 11.8 & 12.0 & 9.3 & 33.1 \\
\hline & 2 & 10.2 & 11.4 & 7.5 & 29.1 \\
\hline & 3 & 14.2 & 10.8 & 11.8 & 36.8 \\
\hline
\end{tabular}

$\mathrm{C}_{5}$ and $\mathrm{C}_{6}$ cycloalkanes represent the highest reactivity, resulting in cyclopentane carboxylic and cyclohexane carboxylic acids with yields of 31 and $43 \%$, respectively (hereinafter, yields are relative to alkane substrate). Corresponding ketones and alcohols are also formed in low amounts (0.3-3.5\%) as by-products of oxidation.

Carboxylation of cycloheptane and cyclooctane results in cyclooctane carboxylic (up to $27 \%$ yield) and cyclononane carboxylic (up to $14 \%$ yield) acids. Herein, the formation of alcohol and ketone by-products is more appreciable, especially in the case of $\mathrm{C}_{8} \mathrm{H}_{16}$ with the yields of cyclooctanol and cyclooctanone of up to $12 \%$ (Table 4 ). 


\subsection{Mild Cu-Catalyzed Carboxylation of Propane}

Compounds 1-3 were also applied as catalysts for the carboxylation of propane (Table 5, Scheme 5) to give iso-butyric acid (main product, $23-33 \%$ yield) and $n$-butyric acid (minor product, $5-7 \%$ yield), as expected for the superior reactivity of the $\mathrm{C}(2)$ atom in propane. Total yields of butyric acids attain $40.1 \%$ (catalyst 3), followed by 33.9 and $27.9 \%$ when using catalysts 1 and 2 , respectively.

Table 5. Single-pot Cu-catalyzed carboxylation of propane ${ }^{\mathrm{a}}$.

\begin{tabular}{cccc}
\hline \multirow{2}{*}{ Catalyst } & \multicolumn{3}{c}{ Yield (\%) $\mathbf{b}, \mathbf{c}$} \\
\cline { 2 - 4 } & i-Butyric Acid & $\boldsymbol{n}^{\text {-Butyric Acid }}$ & Total $^{\mathbf{d}}$ \\
\hline $\mathbf{1}$ & 28.2 & 5.7 & 33.9 \\
$\mathbf{2}$ & 23.1 & 4.8 & 27.9 \\
$\mathbf{3}$ & 33.3 & 6.7 & 40.1 \\
\hline
\end{tabular}

a Conditions: catalysts 1-3 (2.5 $\mu \mathrm{mol})$, propane (3 atm, $1.6 \mathrm{mmol}), \mathrm{H}_{2} \mathrm{O}(2 \mathrm{~mL}) / \mathrm{MeCN}(4 \mathrm{~mL}), \mathrm{CO}(20 \mathrm{~atm}), \mathrm{K}_{2} \mathrm{~S}_{2} \mathrm{O}_{8}$ (1.5 mmol), $4 \mathrm{~h}, 60^{\circ} \mathrm{C}$, stainless-steel autoclave $(20 \mathrm{~mL})$. ${ }^{\mathrm{b}}$ Yields are based on propane, (moles of product per mol of propane) $\times 100 \%$. ${ }^{\mathrm{c}}$ Propane oxidation products (acetone, $i$-propanol) are also formed in minor quantities (up to $1 \%$ total yield). ${ }^{\mathrm{d}}$ Sum of the yields of two acid isomers.

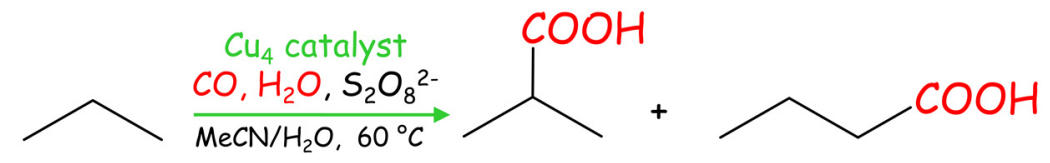

Scheme 5. Single-pot $\mathrm{Cu}$-catalyzed carboxylation of propane to butyric acids.

On the basis of experimental data and taking into consideration prior literature background for related reactions catalyzed by copper compounds [8,34-36], we can propose a simplified mechanism (free-radical type) which includes several steps as follows: (1) homolysis of $\mathrm{K}_{2} \mathrm{~S}_{2} \mathrm{O}_{8}$ to give sulfate radical $\mathrm{SO}_{4}{ }^{\bullet-}$; (2) interaction of $\mathrm{SO}_{4}{ }^{\bullet-}$ with alkane to abstract a hydrogen atom and generate $\mathrm{R}^{\bullet}$ (alkyl radical); (3) formation of $\mathrm{RCO}^{\bullet}$ (acyl radical) via carbonylation of $\mathrm{R}^{\bullet}$ with $\mathrm{CO}$; (4) generation of $\mathrm{RCO}^{+}$ (acyl cation) by oxidation of acyl radical (with an involvement of $\mathrm{Cu}^{\mathrm{II}} / \mathrm{Cu}^{\mathrm{I}}$ redox couple; $\mathrm{Cu}^{\mathrm{II}}$ form is then regenerated through the oxidation with peroxodisulfate); (5) formation of a carboxylic acid product via hydrolysis of acyl cation by water.

\section{Experimental}

\subsection{Materials and Methods}

All reagents and solvents were acquired from commercial suppliers. FTIR spectra were recorded (4000-400 $\mathrm{cm}^{-1}, \mathrm{KBr}$ pellets) on a JASCO FT/IR-4100 Type A or Shimadzu IRAffinity-1S apparatus (abbreviations: vs-very strong, s-strong, $\mathrm{m}$-medium, w-weak, br-broad, sh-shoulder). Elemental analyses (EA) were carried out on a Perkin Elmer PE 2400 Series II analyzer (Laboratory of Analyses, IST). ESI-MS spectra were obtained on an LCQ Fleet apparatus equipped with an electrospray (ESI) ion source (Thermo Scientific, San Jose, CA, USA). Gas chromatography (GC) analyses were carried out on an Agilent Technologies 7820A series gas chromatograph (Flame ionization detector; capillary column: BP20/SGE; carrier gas: He;).

\subsection{Synthetic Procedure and Analytical Data for 1-3}

Firstly, $\mathrm{N}, \mathrm{N}$-bis(2-hydroxyethyl)-2-aminoethanesulfonic acid ( $\mathrm{H}_{3}$ bes, $1 \mathrm{mmol}, 213 \mathrm{mg}$ ) was added to an aqueous solution of $\mathrm{Cu}\left(\mathrm{NO}_{3}\right)_{2} \cdot 3 \mathrm{H}_{2} \mathrm{O}(1 \mathrm{mmol}, 0.1 \mathrm{M}, 10 \mathrm{~mL})$ with stirring under aerobic conditions at room temperature (reaction solution $\mathrm{A})$. Then, benzene carboxylic acid ( $1 \mathrm{mmol}$; benzoic acid for $\mathbf{1}$ (Hba, $122 \mathrm{mg}$ ), 4-hydroxybenzoic acid for $\mathbf{2}$ (Hfhba, $138 \mathrm{mg}$ ), or 3-hydroxybenzoic acid for 3 (Hthba, $138 \mathrm{mg})$ ) was dissolved in aqueous $\mathrm{NH}_{4} \mathrm{OH}(25 \% \mathrm{~m} / \mathrm{m}, 4-12 \mathrm{mmol}$, up to $1.87 \mathrm{~mL})$ to produce reaction solution $\mathrm{B}$. This was slowly added to solution $\mathrm{A}$ and the obtained solution was further stirred 
for 25 minutes, followed by filtration. Slow evaporation of filtrate at room temperature resulted in the self-assembly of green crystals (these were formed within 1-2 weeks). Crystals were collected and dried in air to give complexes 1-3 (yield 50\% based on copper(II) nitrate).

$\left[\mathrm{Cu} u_{4}(\mu \text {-Hbes })_{3}\left(\mu-\mathrm{H}_{2}\right.\right.$ bes $\left.)(\mu-b a)\right] \cdot 2 \mathrm{H}_{2} \mathrm{O}$ (1). Analysis calculated for $\mathbf{1}+\mathrm{NH}_{4} \mathrm{OH}: \mathrm{Cu}_{4} \mathrm{C}_{31} \mathrm{H}_{68} \mathrm{~N}_{5} \mathrm{O}_{25} \mathrm{~S}_{4}$ (molecular weight: $\mathrm{MW}=1292$ ): $\mathrm{C}, 28.79 \% ; \mathrm{H}, 5.26 \% ; \mathrm{N}, 5.42 \%$; S, 9.91\%; found: $\mathrm{C}, 28.99 \% ; \mathrm{H}, 5.13 \%$; $\mathrm{N}, 5.52 \% ; \mathrm{S}, 9.73 \%$. FTIR $\left(\mathrm{KBr}, \mathrm{cm}^{-1}\right): 3568(\mathrm{~m} \mathrm{br}) v\left(\mathrm{OH} / \mathrm{H}_{2} \mathrm{O}\right), 2872(\mathrm{w}) \vee(\mathrm{CH}), 1598(\mathrm{~s}) \delta\left(\mathrm{OH} / \mathrm{H}_{2} \mathrm{O}\right)$, 1546 (vs) vas $(\mathrm{COO}), 1401$ (s) $v_{\mathrm{s}}(\mathrm{COO}), 1241$ (s) $v(\mathrm{C}-\mathrm{C}), 1151$ (vs) $v(\mathrm{C}-\mathrm{N}), 1025$ (vs) $v(\mathrm{C}-\mathrm{S}), 907$ (m), $802(\mathrm{~m}), 782(\mathrm{w}), 750(\mathrm{~m}), 675(\mathrm{~m}), 559(\mathrm{w}), 501(\mathrm{w}), 419(\mathrm{w})$. ESI-MS $( \pm)\left(\mathrm{H}_{2} \mathrm{O}\right)$, selected fragments, MS(+): $m / z: 1099(20 \%)\left[\left\{\mathrm{Cu}_{4}(\mu \text {-Hbes })_{4}\right\}+\mathrm{H}\right]^{+}, 1038(60 \%)\left[\left\{\mathrm{Cu}_{3}(\mu \text {-Hbes })_{2}\left(\mu-\mathrm{H}_{2} \text { bes }\right)_{2}\right\}+\mathrm{H}\right]^{+}, 977$ $(42 \%)\left[\left\{\mathrm{Cu}_{2}\left(\mu-\mathrm{H}_{2} \text { bes }\right)_{4}\right\}+\mathrm{H}\right]^{+}, 825(20 \%)\left[\left\{\mathrm{Cu}_{3}(\mu-\mathrm{Hbes})_{3}\right\}+\mathrm{H}\right]^{+}, 764(70 \%)\left[\left\{\mathrm{Cu}_{2}(\mu-\mathrm{Hbes})\left(\mu-\mathrm{H}_{2} \text { bes }\right)_{2}\right\}\right.$ $+\mathrm{H}]^{+}, 701(95 \%)\left[\left\{\mathrm{Cu}\left(\mu-\mathrm{H}_{2} \text { bes }\right)_{2}\left(\mu-\mathrm{H}_{3} \text { bes }\right)\right\}+\mathrm{H}\right]^{+}, 551(18 \%)\left[\left\{\mathrm{Cu}_{2}(\mu-\mathrm{Hbes})_{2}\right\}+\mathrm{H}\right]^{+}, 488(88 \%)$ $\left[\left\{\mathrm{Cu}\left(\mu-\mathrm{H}_{2} \text { bes }\right)_{2}\right\}+\mathrm{H}\right]^{+}, 427(64 \%)\left[\left(\mathrm{H}_{3} \text { bes }\right)_{2}+\mathrm{H}\right]^{+}, 214(100 \%)\left[\mathrm{H}_{3} \text { bes }+\mathrm{H}\right]^{+} . \mathrm{MS}(-), m / z: 760$ $(5 \%)\left[\mathrm{Cu}_{2}(\mu \text {-Hbes })_{2}\left(\mu-\mathrm{H}_{2} \text { bes }\right)\right]^{-}, 699(8 \%)\left[\mathrm{Cu}\left(\mu-\mathrm{H}_{2} \text { bes }\right)_{3}\right]^{-}, 547(5 \%)\left[\mathrm{Cu}_{2}(\mu-\mathrm{Hbes})(\mu \text {-bes })\right]^{-}, 425(42 \%)$ $\left[\left(\mathrm{H}_{3} \text { bes }\right)\left(\mathrm{H}_{2} \text { bes }\right)\right]^{-}, 212(100 \%)\left[\mathrm{H}_{2} \text { bes }\right]^{-}, 121(35 \%)[\mathrm{ba}]^{-}$.

$\left[\mathrm{Cu} u_{4}(\mu \text {-Hbes })_{3}\left(\mu-\mathrm{H}_{2}\right.\right.$ bes $\left.)(\mu-f h b a)\right] \cdot 2 \mathrm{H}_{2} \mathrm{O}(2)$. Analysis calculated for $2+\mathrm{NH}_{4} \mathrm{OH}:\left(\mathrm{Cu}_{4} \mathrm{C}_{31} \mathrm{H}_{70} \mathrm{~N}_{6} \mathrm{O}_{27} \mathrm{~S}_{4}\right)$ (molecular weight: $\mathrm{MW}=1325$ ): $\mathrm{C}, 28.08 \% ; \mathrm{H}, 5.28 \% ; \mathrm{N}, 5.81 \% ; \mathrm{S}, 9.66 \%$. found: $\mathrm{C}, 28.20 \% ; \mathrm{H}$, $5.03 \%$; N , 6.06\%; S, 9.93\%. FTIR (KBr, cm $\left.{ }^{-1}\right): 3541(\mathrm{~m} \mathrm{br}) \vee\left(\mathrm{OH} / \mathrm{H}_{2} \mathrm{O}\right), 2880(\mathrm{w}) \vee(\mathrm{CH}), 1609(\mathrm{~s})$ $\delta\left(\mathrm{OH} / \mathrm{H}_{2} \mathrm{O}\right), 1540(\mathrm{~s}) v_{\mathrm{as}}(\mathrm{COO}), 1398(\mathrm{vs}) v_{\mathrm{s}}(\mathrm{COO}), 1242(\mathrm{vs}) v(\mathrm{C}-\mathrm{C}), 1150(\mathrm{vs}) v(\mathrm{C}-\mathrm{N}), 1024$ (vs) $v(C-S), 905(\mathrm{~m}), 864(\mathrm{w}), 794(\mathrm{w}), 750(\mathrm{w}), 676(\mathrm{w}), 630(\mathrm{w}), 567(\mathrm{w}), 503(\mathrm{w}), 460(\mathrm{w}), 423(\mathrm{w})$. ESI-MS $( \pm)\left(\mathrm{H}_{2} \mathrm{O}\right)$, selected fragments, MS $(+), m / z: 1376(5 \%)\left[\left\{\mathrm{Cu}_{4}(\mu \text {-Hbes })_{3}\left(\mu-\mathrm{H}_{2}\right.\right.\right.$ bes $\left.)\right\}\{\mu \text {-Hfhba }\}_{2}$ $+\mathrm{H}]^{+}, 1099(16 \%)\left[\left\{\mathrm{Cu}_{4}(\mu-\mathrm{Hbes})_{4}\right\}+\mathrm{H}\right]^{+}, 1099(18 \%)\left[\left\{\mathrm{Cu}_{4}(\mu-\mathrm{Hbes})_{4}\right\}+\mathrm{H}\right]^{+}, 1038(58 \%)$ $\left[\left\{\mathrm{Cu}_{3}(\mu-\mathrm{Hbes})_{2}\left(\mu-\mathrm{H}_{2} \text { bes }\right)_{2}\right\}+\mathrm{H}\right]^{+}, 977(50 \%)\left[\left\{\mathrm{Cu}_{2}\left(\mu-\mathrm{H}_{2} \text { bes }\right)_{4}\right\}+\mathrm{H}\right]^{+}, 825(20 \%)\left[\left\{\mathrm{Cu}_{3}(\mu-\mathrm{Hbes})_{3}\right\}+\right.$ $\mathrm{H}]^{+}, 764(68 \%)\left[\left\{\mathrm{Cu}_{2}(\mu \text {-Hbes })\left(\mu-\mathrm{H}_{2} \text { bes }\right)_{2}\right\}+\mathrm{H}\right]^{+}, 701(100 \%)\left[\left\{\mathrm{Cu}\left(\mu-\mathrm{H}_{2} \text { bes }\right)_{2}\left(\mu-\mathrm{H}_{3} \text { bes }\right)\right\}+\mathrm{H}\right]^{+}, 551$ $(15 \%)\left[\left\{\mathrm{Cu}_{2}(\mu-\mathrm{Hbes})_{2}\right\}+\mathrm{H}\right]^{+}, 488(66 \%)\left[\left\{\mathrm{Cu}\left(\mu-\mathrm{H}_{2} \text { bes }\right)_{2}\right\}+\mathrm{H}\right]^{+}, 427(52 \%)\left[\left(\mathrm{H}_{3} \text { bes }\right)_{2}+\mathrm{H}\right]^{+}, 275(18 \%)$ $[\{\mathrm{Cu}(\mu-\mathrm{Hbes})\}+\mathrm{H}]^{+}, 214(54 \%)[\{\text { bes }\}+\mathrm{H}]^{+}$. MS $(-), m / z: 760(5 \%)\left[\mathrm{Cu}_{2}(\mu-\mathrm{Hbes})_{2}\left(\mu-\mathrm{H}_{2} \text { bes }\right)\right]^{-}, 699(8 \%)$ $\left[\mathrm{Cu}\left(\mu-\mathrm{H}_{2} \text { bes }\right)_{3}\right]^{-}, 547(5 \%)\left[\mathrm{Cu}_{2}(\mu \text {-Hbes })(\mu \text {-bes })\right]^{-}, 425(42 \%)\left[\left(\mathrm{H}_{3} \text { bes }\right)\left(\mathrm{H}_{2} \text { bes }\right)\right]^{-}, 212(100 \%)\left[\mathrm{H}_{2} \text { bes }\right]^{-}$, $137(34 \%)\left[\mathrm{fhba}^{-}\right.$.

$\left[\mathrm{Cu}_{4}(\mu \text {-Hbes })_{3}\left(\mu-\mathrm{H}_{2}\right.\right.$ bes $)(\mu$-thba) $] \cdot 2 \mathrm{H}_{2} \mathrm{O}(3)$. Analysis calculated for $3+0.75 \mathrm{NH}_{4} \mathrm{OH}:\left(\mathrm{Cu}_{4} \mathrm{C}_{31} \mathrm{H}_{66.75} \mathrm{~N}_{4.75} \mathrm{O}_{25.75} \mathrm{~S}_{4}\right)$ (molecular weight: $\mathrm{MW}=1299.25$ ): $\mathrm{C}, 28.63 \% ; \mathrm{H}, 5.16 \% ; \mathrm{N}, 5.12 \% ; \mathrm{S}, 9.85 \%$. found: $\mathrm{C}, 28.86 \% ; \mathrm{H}, 5.09 \%$; $\mathrm{N}, 5.23 \%$; S, 9.70\%. FTIR (KBr, cm $\left.{ }^{-1}\right): 3568(\mathrm{~m} \mathrm{br}) v\left(\mathrm{OH} / \mathrm{H}_{2} \mathrm{O}\right), 2870(\mathrm{w}) v(\mathrm{CH}), 1600(\mathrm{~s}) \delta\left(\mathrm{OH} / \mathrm{H}_{2} \mathrm{O}\right)$, $1546(\mathrm{~s}) v_{\mathrm{as}}(\mathrm{COO}), 1401(\mathrm{~s}) v_{\mathrm{s}}(\mathrm{COO}), 1240(\mathrm{~m}) v(\mathrm{C}-\mathrm{C}), 1151$ (vs) $v(\mathrm{C}-\mathrm{N}), 1025$ (vs) $v(\mathrm{C}-\mathrm{S}), 907(\mathrm{~m}), 802$ $(\mathrm{w}), 782(\mathrm{w}), 750(\mathrm{~m}), 675(\mathrm{w}), 560(\mathrm{w}), 501(\mathrm{w}), 419(\mathrm{w})$. ESI-MS $( \pm)\left(\mathrm{H}_{2} \mathrm{O}\right)$, selected fragments, MS $(+)$, $m / z: 1376(5 \%)\left[\left\{\mathrm{Cu}_{4}(\mu \text {-Hbes })_{3}\left(\mu-\mathrm{H}_{2} \text { bes }\right)\right\}\{\mu \text {-Hthba }\}_{2}+\mathrm{H}\right]^{+}, 1099(20 \%)\left[\left\{\mathrm{Cu}_{4}(\mu-\mathrm{Hbes})_{4}\right\}+\mathrm{H}\right]^{+}, 1038$ $(60 \%)\left[\left\{\mathrm{Cu}_{3}(\mu-\mathrm{Hbes})_{2}\left(\mu-\mathrm{H}_{2} \text { bes }\right)_{2}\right\}+\mathrm{H}\right]^{+}, 977(55 \%)\left[\left\{\mathrm{Cu}_{2}\left(\mu-\mathrm{H}_{2} \text { bes }\right)_{4}\right\}+\mathrm{H}\right]^{+}, 825(30 \%)\left[\left\{\mathrm{Cu}_{3}(\mu-\mathrm{Hbes})_{3}\right\}\right.$ $+\mathrm{H}]^{+}, 764(90 \%)\left[\left\{\mathrm{Cu}_{2}(\mu-\mathrm{Hbes})\left(\mu-\mathrm{H}_{2} \text { bes }\right)_{2}\right\}+\mathrm{H}\right]^{+}, 701(100 \%)\left[\left\{\mathrm{Cu}\left(\mu-\mathrm{H}_{2} \text { bes }\right)_{2}\left(\mu-\mathrm{H}_{3} \text { bes }\right)\right\}+\mathrm{H}\right]^{+}, 551$ $(18 \%)\left[\left\{\mathrm{Cu}_{2}(\mu \text {-Hbes })_{2}\right\}+\mathrm{H}\right]^{+}, 488(86 \%)\left[\left\{\mathrm{Cu}\left(\mu-\mathrm{H}_{2} \text { bes }\right)_{2}\right\}+\mathrm{H}\right]^{+}, 427(52 \%)\left[\left(\mathrm{H}_{3} \text { bes }\right)_{2}+\mathrm{H}\right]^{+}, 275(18 \%)$ $[\{\mathrm{Cu}(\mu \text {-Hbes })\}+\mathrm{H}]^{+}, 214(47 \%)\left[\mathrm{H}_{3} \text { bes }+\mathrm{H}\right]^{+} . \mathrm{MS}(-), m / z: 823(5 \%)\left[\mathrm{Cu}_{3}\left(\mu-\mathrm{H}_{2} \text { bes }\right)_{2}(\mu-\mathrm{Hbes})\right]^{-}, 760$ $(5 \%)\left[\mathrm{Cu}_{2}\left(\mu-\mathrm{H}_{2} \text { bes }\right)_{2}(\mu \text {-Hbes })\right]^{-}, 699(8 \%)\left[\mathrm{Cu}\left(\mu-\mathrm{H}_{2} \text { bes }\right)_{3}\right]^{-}, 547(10 \%)\left[\mathrm{Cu}_{2}(\mu \text {-Hbes })(\mu \text {-bes })\right]^{-}, 425(32 \%)$ $\left[\left(\mathrm{H}_{3} \text { bes }\right)\left(\mathrm{H}_{2} \text { bes }\right)\right]^{-}, 274(5 \%)[\mathrm{Cu}(\mu-\mathrm{Hbes})]^{-}, 212(100 \%)\left[\mathrm{H}_{2} \mathrm{bes}\right]^{-}, 137(22 \%)[\text { thba }]^{-}$.

\subsection{X-ray Diffraction}

Single crystals of 1-3 were mounted with Fomblin@ in a cryoloop. Diffraction data were obtained on Bruker AXS-KAPPA APEX II or BRUKER D8 QUEST diffractometers (graphite-monochromated radiation, Mo $\mathrm{K} \alpha, \lambda=0.7107 \AA$, $298 \mathrm{~K}$ ). X-ray generator parameters were $50 \mathrm{kV}$ and $30 \mathrm{~mA}$. APEX2 [42] and APEX3 [43] programs were used to monitor the collection of X-ray data. SAINT [44] and SADABS [45] were applied for correction of all data for Lorentzian, polarization, and absorption effects. SHELXT was applied to solve the structures, while SHELXL-97 was used for refinement (full-matrix least-squares on $F^{2}$ ) [46]. This software is a part of the WINGX-Version 2014.1 package [47]. All atoms (with the exception of $\mathrm{H}$ atoms) were refined anisotropically. For non-H atoms, full-matrix 
least-squares refinement was used with anisotropic thermal parameters. In 3, water $\mathrm{O}$ atoms were refined with 0.5 occupancy. A twin matrix was applied to 3 . All the hydrogen atoms bonded to carbon atoms were inserted in idealized positions and allowed to refine at the parent carbon atom. $\mathrm{H}$ atoms on the aminoalcohol moieties were localized by the electron density map and their positions were fixed. Regarding the hydroxyl groups in the benzene carboxylate in $\mathbf{3}$ and $\mathbf{2}$, the hydrogen atoms were inserted in idealized positions and allowed to refine at the parent $\mathrm{O}$ atom. With the exception of 2 , the water hydrogen atoms were not possible to locate. Despite several attempts to recrystallize the compounds and several data collections for each sample, crystals of $\mathbf{1}$ and $\mathbf{3}$ were of low quality and the refinement of these crystal structures resulted in high $R_{\text {int }}$ and final $R_{1}$ and $w R_{2}$ values or completeness issues (for $\mathbf{3}$ ). The structure of $\mathbf{2}$ represents the best refinement parameters (Table S1, Supplementary Materials) and, thus, is discussed in detail as a representative example. The structural data for 1-3 were deposited as CIF files within the Cambridge Crystallographic Data Base (CCDC 1899840-1899842).

\subsection{Catalytic Oxidation of Cycloalkanes}

Catalytic tests were performed in glass reactors (equipped with a condenser) under aerobic conditions and under vigorous stirring at $50{ }^{\circ} \mathrm{C}$, using $\mathrm{MeCN}$ as a solvent (up to $2.5 \mathrm{~mL}$ of total reaction volume). Total volume refers to all reagents and solvent $\left(\mathrm{H}_{2} \mathrm{O}_{2}\right.$, alkane, GC standard, $\mathrm{H}_{2} \mathrm{O}$, and $\mathrm{MeCN})$. The typical procedure was as follows: catalyst 1-3 $(2.5 \mu \mathrm{mol})$ was introduced into a MeCN solution, followed by the addition of an acid promoter $(50 \mu \mathrm{mol})$ and GC internal standard $\left(\mathrm{MeNO}_{2}\right.$, $250 \mu \mathrm{L})$. Then, an alkane substrate $(1 \mathrm{mmol})$ and hydrogen peroxide $\left(50 \%\right.$ in $\left.\mathrm{H}_{2} \mathrm{O}, 5 \mathrm{mmol}\right)$ were added. The oxidation reactions were followed by withdrawing small aliquots of the reaction mixture at different time periods. Prior to GC (gas chromatography) analysis, the aliquots were treated with solid $\mathrm{PPh}_{3}$ for reducing alkyl hydroperoxides (primary products in cycloalkane reactions) and remaining $\mathrm{H}_{2} \mathrm{O}_{2}$; all the product yields were calculated based on GC data after the treatment with solid $\mathrm{PPh}_{3}$. Generation of alkyl hydroperoxides as primary products was corroborated by doing the GC analyses of selected samples twice, before and after the treatment with solid $\mathrm{PPh}_{3}$ (Shul'pin's method) [5,15]. Peaks were attributed by comparing the obtained chromatograms with those of commercially available samples of products.

\subsection{Catalytic Oxidation of Propane}

The typical procedure was as follows: catalyst 1-3 $(2.5 \mu \mathrm{mol})$ was introduced in an acetonitrile solution, and then an acid promoter (50 $\mu \mathrm{mol}), \mathrm{MeNO}_{2}$ (GC internal standard, $250 \mu \mathrm{L}$ ), and hydrogen peroxide ( $50 \%$ in $\mathrm{H}_{2} \mathrm{O}, 5 \mathrm{mmol}$ ) were added. A stainless-steel autoclave (total volume of $20.0 \mathrm{~mL}$ ) was closed, pressurized with $3 \mathrm{~atm}$ of propane substrate, and kept under stirring at $50{ }^{\circ} \mathrm{C}$ (oil bath and magnetic stirrer) for $4 \mathrm{~h}$. The autoclave was then cooled down and degassed. Samples of the reaction mixture were treated with $\mathrm{PPh}_{3}$ and analyzed by GC for quantification of products (internal standard method).

\subsection{Catalytic Carboxylation of Alkanes}

The typical procedure was as follows: catalyst 1-3 $(2.5 \mu \mathrm{mol}), \mathrm{H}_{2} \mathrm{O}(2.0 \mathrm{~mL}), \mathrm{MeCN}(4.0 \mathrm{~mL})$, cycloalkane $(1.0 \mathrm{mmol})$, and $\mathrm{K}_{2} \mathrm{~S}_{2} \mathrm{O}_{8}(1.50 \mathrm{mmol})$ were introduced into a stainless-steel autoclave (total volume of $20.0 \mathrm{~mL}$ ). Then, the autoclave was closed and flushed three times with $\mathrm{CO}$ for air removal and pressurized with carbon monoxide (20 atm). In the case of propane carboxylation, the reactor was first flushed and pressurized with propane followed by the addition of $\mathrm{CO}$. The reaction mixture was stirred at $60^{\circ} \mathrm{C}$ for $4 \mathrm{~h}$ (oil bath and magnetic stirrer). After this period, the autoclave was cooled in an ice bath, degassed, and opened. The reaction mixture was transferred to a glass flask. $\mathrm{Et}_{2} \mathrm{O}(9.0 \mathrm{~mL})$ and GC internal standard (cycloheptanone, $45 \mu \mathrm{L}$ ) were introduced; cyclohexanone was the GC standard in the carboxylation of cycloheptane. After stirring the obtained mixture for $10 \mathrm{~min}$, the aliquots were taken from an organic layer. These were subjected to GC analysis for the quantification (internal 
standard method) of carboxylic acids as principal products (ketones and alcohols were also formed as by-products in minor amounts). Peaks were attributed by comparing the obtained chromatograms with those of commercially available samples of products.

\section{Conclusions}

In this study, we used a self-assembly synthesis to prepare three new tetracopper(II) complexes, derived from a trifunctional aminoalcohol sulfonic acid (main building block) and a benezene carboxylic acid (supporting ligand). The obtained products $\left[\mathrm{Cu}_{4}(\mu-\mathrm{Hbes})_{3}\left(\mu-\mathrm{H}_{2}\right.\right.$ bes $\left.)(\mu-\mathrm{L})\right] \cdot 2 \mathrm{H}_{2} \mathrm{O}$ $\left(\mathrm{L}=\mathrm{ba}^{-}(1), \mathrm{fhba}^{-}(2)\right.$, and thba $\left.{ }^{-}(3)\right)$ were fully characterized and reveal a similar type of tetracopper(II) core. These cores are soluble in aqueous medium and were used as catalysts for oxidative $\mathrm{C}-\mathrm{H}$ functionalization of gaseous (propane) and liquid alkanes $\left(\mathrm{C}_{5}-\mathrm{C}_{8}\right.$ cycloalkanes).

In fact, the obtained compounds 1-3 act as efficient and versatile homogeneous catalysts for the oxidation of cycloalkanes with hydrogen peroxide to produce cyclic alcohols and ketones, with total yields attaining $27 \%$ (yields are based on cycloalkane substrate). Propane oxidation into a mixture of the $\mathrm{C}_{3}$ oxidation products was also achieved. The influence of various parameters of the oxidation reaction was investigated in detail, in addition to mechanistic and selectivity features. Moreover, compounds 1-3 also catalyze the mild carboxylation of propane and $C_{5}-C_{8}$ cycloalkanes to give carboxylic acids in as high as $41 \%$ yield (based on alkane substrate). The obtained yields are remarkable considering the inertness of alkane substrates and mild reaction conditions applied [1-8].

Given the multicopper nature of active sites in some enzymes (i.e., multicopper oxidases, particulate methane monooxygenase) [20-22,48], the mild oxidative functionalization of alkanes using such bioinspired multicopper catalysts represents a particularly interesting research direction. Future research will also focus on the design of new structurally related coordination compounds and their application as catalysts in the mild functionalization of saturated hydrocarbons. The search for more efficient systems, optimization of reaction parameters, and widening of the substrate scope will be pursued.

Supplementary Materials: The following are available online at http:/ /www.mdpi.com/2073-4344/9/4/321/s1: Table S1: crystal data for 1-3; Figure S1: crystal structures of 1 and 3; Figure S2: IR spectra and their discussion; Figures S3-S7: ESI-MS data and their discussion; Figures S8-S10: additional catalysis data.

Author Contributions: Conceptualization, M.V.K. and A.M.K.; data curation, I.F.M.C, M.V.K., V.A., and T.A.F.; funding acquisition, M.V.K. and A.M.K.; investigation, I.F.M.C., M.V.K., V.A., and T.A.F.; methodology, M.V.K.; supervision, A.M.K.; visualization, A.M.K. and M.V.K.; writing-original draft, I.F.M.C., T.A.F., M.V.K., V.A., and A.M.K.; writing-review and editing, A.M.K.

Funding: This work was supported by the Foundation for Science and Technology (FCT) and Portugal 2020 (projects IF/01395/2013/CP1163/CT005, CEECIND/03708/2017, UID/QUI/00100/2013, LISBOA-01-0145FEDER-029697, and REM2013). The publication was also prepared with the support of the RUDN University Program 5-100.

Acknowledgments: A.M.K. acknowledges the COST Action CA15106 (CHAOS). T.A.F. acknowledges the FCT for BPD grant SFRH/BPD/119980/2016. We thank S. Dias for experimental assistance, and M. C. Oliveira and A. Dias for ESI-MS $( \pm)$ measurements.

Conflicts of Interest: The authors declare no conflicts of interest.

\section{References}

1. Shilov, A.E.; Shul'pin, G.B. Activation and Catalytic Reactions of Saturated Hydrocarbons in the Presence of Metal Complexes; Kluwer Acad. Publ.: Dordrecht, The Netherlands, 2000.

2. Olah, G.A.; Molnár, Á. Hydrocarbon Chemistry; Wiley: Hoboken, NJ, USA, 2003.

3. Alkane, C.-H. Activation by Single-Site Metal Catalysis; Pérez, P.J., Ed.; Springer: New York, NY, USA, 2012.

4. Nesterov, D.S.; Nesterova, O.V.; Pombeiro, A.J.L. Homo- and heterometallic polynuclear transition metal catalysts for alkane C-H bonds oxidative functionalization: Recent advances. Coord. Chem. Rev. 2018, 355, 199-222. [CrossRef] 
5. Shul'pin, G.B. Hydrocarbon Oxygenations with Peroxides Catalyzed by Metal Compounds. Mini-Rev. Org. Chem. 2009, 6, 95-104. [CrossRef]

6. Fokin, A.A.; Schreiner, P.R. Selective Alkane Transformations via Radicals and Radical Cations: Insights into the Activation Step from Experiment and Theory. Chem. Rev. 2002, 102, 1551-1594. [CrossRef] [PubMed]

7. Labinger, J.A.; Bercaw, J.E. Understanding and exploiting C-H bond activation. Nature 2002, 417, 507-514. [CrossRef]

8. Kirillov, A.M.; Kirillova, M.V.; Pombeiro, A.J.L. Multicopper complexes and coordination polymers for mild oxidative functionalization of alkanes. Coord. Chem. Rev. 2012, 256, 2741-2759. [CrossRef]

9. Nesterova, O.V.; Kopylovich, M.N.; Nesterov, D.S. Stereoselective oxidation of alkanes with m-CPBA as an oxidant and cobalt complex with isoindole-based ligands as catalysts. RSC Adv. 2016, 6, 93756-93767. [CrossRef]

10. Antonangelo, A.R.; Grazia Bezzu, C.; McKeown, N.B.; Nakagaki, S. Highly active manganese porphyrin-based microporous network polymers for selective oxidation reactions. J. Catal. 2019, 369, 133-142. [CrossRef]

11. Talsi, E.P.; Bryliakov, K.P. Chemo- and stereoselective $\mathrm{CH}$ oxidations and epoxidations/cis-dihydroxylations with $\mathrm{H} 2 \mathrm{O} 2$, catalyzed by non-heme iron and manganese complexes. Coord. Chem. Rev. 2012, 256, 1418-1434. [CrossRef]

12. Ottenbacher, R.V.; Talsi, E.P.; Bryliakov, K.P. Direct Selective Oxidative Functionalization of C-H Bonds with $\mathrm{H}_{2} \mathrm{O}_{2}$ : Mn-Aminopyridine Complexes Challenge the Dominance of Non-Heme Fe Catalysts. Molecules 2016, 21, 1454. [CrossRef]

13. Shilov, A.E.; Shul'pin, G.B. Activation of C-H Bonds by Metal Complexes. Chem. Rev. 1997, 97, 2879-2932. [CrossRef]

14. Shul'pin, G.B. New Trends in Oxidative Functionalization of Carbon-Hydrogen Bonds: A Review. Catalysts 2016, 6, 50. [CrossRef]

15. Shul'pin, G.B. Metal-catalyzed hydrocarbon oxygenations in solutions: The dramatic role of additives: A review. J. Mol. Catal. A Chem. 2002, 189, 39-66. [CrossRef]

16. Nesterov, D.S.; Nesterova, O.V.; Guedes da Silva, M.F.C.; Pombeiro, A.J.L. Catalytic behaviour of a novel Fe(III) Schiff base complex in the mild oxidation of cyclohexane. Catal. Sci. Technol. 2015, 5, 1801-1812. [CrossRef]

17. Nesterov, D.S.; Nesterova, O.V.; Kopylovich, M.N.; Pombeiro, A.J.L. Pronounced retention of stereoconfiguration upon $\mathrm{sp}_{3} \mathrm{C}-\mathrm{H}$ bonds hydroxylation of dimethylcyclohexanes and decahydronaphthalenes with m-CPBA oxidant and a Co-phthalocyanine catalyst. Mol. Catal. 2018, 459, 8-15. [CrossRef]

18. Gupta, S.; Kirillova, M.V.; da Silva, M.F.C.G.; Pombeiro, A.J.L.; Kirillov, A.M. Alkali metal directed assembly of heterometallic $\mathrm{V}^{\mathrm{v}} / \mathrm{M}(\mathrm{M}=\mathrm{Na}, \mathrm{K}, \mathrm{Cs})$ coordination polymers: Structures, topological analysis, and oxidation catalytic properties. Inorg. Chem. 2013, 52, 8601-8611. [CrossRef]

19. Bäckvall, J.-E. (Ed.) Modern Oxidation Methods, 2nd ed.; John Wiley \& Sons: Hoboken, NJ, USA, 2011.

20. Karlin, K.D.; Tyeklar, Z. (Eds.) Bioinorganic Chemistry of Copper; Springer: Berlin, Germany, 2012.

21. Itoh, S.; Rokita, S. (Eds.) Copper-Oxygen Chemistry; Wiley: New York, NY, USA, 2011.

22. Brissos, R.S.; Garcia, S.; Presa, A.; Gamez, P. Bio-related copper-mediated oxidative processes. Comments Inorg. Chem. 2011, 32, 219-245. [CrossRef]

23. Fernandes, T.A.; Santos, C.I.M.; André, V.; Kłak, J.; Kirillova, M.V.; Kirillov, A.M. Aqua-Soluble Copper(II) Coordination Polymers Self-assembled from Aminoalcohols and Pyromellitic Acid: Highly Active Pre-catalysts for the Mild Water-promoted Oxidation of Alkanes. Inorg. Chem. 2016, 55, 125-135. [CrossRef]

24. Fernandes, T.A.; Santos, C.I.M.; André, V.; Dias, S.S.P.; Kirillova, M.V.; Kirillov, A.M. New aqua-soluble dicopper(II) aminoalcoholate cores for mild and water-assisted catalytic oxidation of alkanes. Catal. Sci. Technol. 2016, 6, 4584-4593. [CrossRef]

25. Dias, S.S.P.; Kirillova, M.V.; André, V.; Kłak, J.; Kirillov, A.M. New tricopper(II) cores self-assembled from aminoalcohol biobuffers and homophthalic acid: Synthesis, structural and topological features, magnetic properties and mild catalytic oxidation of cyclic and linear C5-C8 alkanes. Inorg. Chem. Front. 2015, 2, 525-537. [CrossRef]

26. Dias, S.S.P.; Kirillova, M.V.; André, V.; Kłak, J.; Kirillov, A.M. New Tetracopper (II) Cubane Cores Driven by a Diamino Alcohol: Self-assembly Synthesis, Structural and Topological Features, and Magnetic and Catalytic Oxidation Properties. Inorg. Chem. 2015, 54, 5204-5212. [CrossRef]

27. Kulakova, A.N.; Bilyachenko, A.N.; Korlyukov, A.A.; Shul'pina, L.S.; Bantreil, X.; Lamaty, F.; Shubina, E.S.; Levitsky, M.M.; Ikonnikova, N.S.; Shul'pin, G.B. A new "bicycle helmet"-like copper(II) sodiumphenylsilses quioxane. Synthesis, structure and catalytic activity. Dalton Trans. 2018, 47, 15666-15669. [CrossRef] [PubMed] 
28. Levitsky, M.M.; Yalymov, A.I.; Kulakova, A.N.; Petrov, A.A.; Bilyachenko, A.N. Cage-like metallsilsesquioxanes in catalysis: A review. J. Mol. Cat. A Chem. 2017, 426, 297-304. [CrossRef]

29. Good, N.E.; Winget, G.D.; Winter, W.; Connolly, T.N.; Izawa, S.; Sing, R.M.M. Hydrogen ion buffers for biological research. Biochemistry 1966, 5, 467-477. [CrossRef] [PubMed]

30. Ferguson, W.J.; Braunschweiger, K.I.; Braunschweiger, W.R.; Smith, J.R.; McCormick, J.J.; Wasmann, C.C.; Jarvis, N.P.; Bell, D.H.; Good, N.E. Hydrogen ion buffers for biological research. Anal. Biochem. 1980, 104, 300-310. [CrossRef]

31. Groom, C.R.; Bruno, I.J.; Lightfoot, M.P.; Ward, S.C. The Cambridge Structural Database. Acta Cryst. 2016, B72, 171-179. [CrossRef]

32. Kirillov, A.M.; Coelho, J.A.S.; Kirillova, M.V.; Guedes da Silva, M.F.C.; Nesterov, D.S.; Gruenwald, K.R.; Haukka, M.; Pombeiro, A.J.L. Bringing an “Old” Biological Buffer to Coordination Chemistry: New 1D and 3D Coordination Polymers with $\left[\mathrm{Cu}_{4}(\mathrm{Hbes})_{4}\right]$ Cores for Mild Hydrocarboxylation of Alkanes. Inorg. Chem. 2010, 49, 6390-6392. [CrossRef]

33. Kirillova, M.V.; Kirillov, A.M.; Martins, A.N.C.; Graiff, C.; Tiripicchio, A.; Pombeiro, A.J.L. Topologically Unique Heterometallic Cu ${ }^{\text {II }}$ / Li Coordination Polymers Self-Assembled from N,N-bis(2-Hydroxyethyl)-2aminoethanesulfonic Acid Biobuffer: Versatile Catalyst Precursors for Mild Hydrocarboxylation of Alkanes to Carboxylic Acids. Inorg. Chem. 2012, 51, 5224-5234. [CrossRef]

34. Kirillova, M.V.; Kirillov, A.M.; Pombeiro, A.J.L. Mild, single-pot hydrocarboxylation of gaseous alkanes to carboxylic acids in metal-free and copper-promoted aqueous systems. Chem. Eur. J. 2010, 16, 9485-9493. [CrossRef] [PubMed]

35. Kirillova, M.V.; Kirillov, A.M.; Kuznetsov, M.L.; Silva, J.A.L.; Fraústo da Silva, J.J.R.; Pombeiro, A.J.L. Alkanes to carboxylic acids in aqueous medium: Metal-free and metal-promoted highly efficient and mild conversions. Chem. Commun. 2009, 2353-2355. [CrossRef]

36. Kirillova, M.V.; Kirillov, A.M.; Pombeiro, A.J.L. Metal-free and copper-promoted single-pot hydrocarboxylation of cycloalkanes to carboxylic acids in aqueous medium. Adv. Synth. Catal. 2009, 351, 2936-2948. [CrossRef]

37. Kirillov, A.M.; Haukka, M.; da Silva, M.F.C.G.; Pombeiro, A.J.L. Preparation and crystal structures of benzoylhydrazido- and -diazenidorhenium complexes with $\mathrm{N}, \mathrm{O}$-ligands and their catalytic activity towards peroxidative oxidation of cycloalkanes. Eur. J. Inorg. Chem. 2005, 2071-2080. [CrossRef]

38. Schuchardt, U.; Cardoso, D.; Sercheli, R.; Pereira, R.; da Cruz, R.S.; Guerreiro, M.C.; Mandelli, D.; Spinace, E.V.; Pires, E.L. Cyclohexane Oxidation Continues to be a Challenge. Appl. Catal. A Gen. 2001, 211, 1-17. [CrossRef]

39. Wittcoff, H.; Reuben, B.G.; Plotkin, J.S. Industrial Organic Chemicals, 2nd ed.; Wiley: New York, NY, USA, 2004.

40. Kirillov, A.M.; Shul'pin, G.B. Pyrazinecarboxylic acid and analogs: Highly efficient co-catalysts in the metal-complex-catalyzed oxidation of organic compounds. Coord. Chem. Rev. 2013, 257, 732-754. [CrossRef]

41. Armakola, E.; Colodrero, R.M.P.; Bazaga-García, M.; Salcedo, I.R.; Choquesillo-Lazarte, D.; Cabeza, A.; Kirillova, M.V.; Kirillov, A.M.; Demadis, K.D. Three-Component Copper-Phosphonate-Auxiliary Ligand Systems: Proton Conductors and Efficient Catalysts in Mild Oxidative Functionalization of Cycloalkanes. Inorg. Chem. 2018, 57, 10656-10666. [CrossRef] [PubMed]

42. APEX2. Ver. 2014.11-0; Bruker-AXS: Billerica, MA, USA, 2014.

43. APEX3. Ver. 2017.3-0; Bruker-AXS: Billerica, MA, USA, 2017.

44. SAINT; Bruker-AXS: Billerica, MA, USA, 2014/2017.

45. SADABS; Bruker-AXS: Billerica, MA, USA, 2014/2017.

46. Sheldrick, G.M. A short history of SHELX. Acta Cryst. 2008, A64, 112-122. [CrossRef] [PubMed]

47. Farrugia, L.J. WinGX-Version 1.80.05. J. Appl. Cryst. 1999, 32, 837-838. [CrossRef]

48. Ayala, M.; Torres, E. Enzymatic activation of alkanes: Constraints and prospective. Appl. Catal. A 2004, 272, 1-13. [CrossRef]

(C) 2019 by the authors. Licensee MDPI, Basel, Switzerland. This article is an open access article distributed under the terms and conditions of the Creative Commons Attribution (CC BY) license (http:/ / creativecommons.org/licenses/by/4.0/). 